\title{
Sensitivity of mesoscale model urban boundary layer meteorology to the scale of urban representation
}

\author{
D. D. Flagg ${ }^{1, *}$ and P. A. Taylor ${ }^{1}$ \\ ${ }^{1}$ York University, Toronto, Ontario, Canada \\ "now at: Meteorologisches Institut, Universität Hamburg, Hamburg, Germany
}

Received: 28 July 2010 - Published in Atmos. Chem. Phys. Discuss.: 3 November 2010

Revised: 11 March 2011 - Accepted: 21 March 2011 - Published: 30 March 2011

\begin{abstract}
Mesoscale modeling of the urban boundary layer requires careful parameterization of the surface due to its heterogeneous morphology. Model estimated meteorological quantities, including the surface energy budget and canopy layer variables, will respond accordingly to the scale of representation. This study examines the sensitivity of the surface energy balance, canopy layer and boundary layer meteorology to the scale of urban surface representation in a real urban area (Detroit-Windsor (USA-Canada)) during several dry, cloud-free summer periods. The model used is the Weather Research and Forecasting (WRF) model with its coupled single-layer urban canopy model. Some model verification is presented using measurements from the Border Air Quality and Meteorology Study (BAQS-Met) 2007 field campaign and additional sources. Case studies span from "neighborhood" (10 s $\sim 308 \mathrm{~m})$ to very coarse $(120 \mathrm{~s}$ $\sim 3.7 \mathrm{~km}$ ) resolution. Small changes in scale can affect the classification of the surface, affecting both the local and gridaverage meteorology. Results indicate high sensitivity in turbulent latent heat flux from the natural surface and sensible heat flux from the urban canopy. Small scale change is also shown to delay timing of a lake-breeze front passage and can affect the timing of local transition in static stability.
\end{abstract}

\section{Introduction}

The urban boundary layer (UBL) is a term frequently used to refer to the atmospheric boundary layer (ABL) over an urban area, a type of $\mathrm{ABL}$ distinguished by its underlying complex and heterogeneous surface. Analogous to a tall vegetation canopy, the urban surface consists of buildings that disrupt the flow of air within and above, generating turbulent eddies

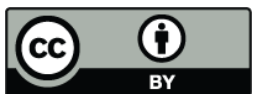

Correspondence to: D. D. Flagg (david.flagg@zmaw.de) and reducing wind speed in the vicinity of the canopy (roof) top and within the canopy (Roth, 2000). In addition, the urban surface is typically composed of artificial materials (asphalt, concrete, brick, etc.) whose physical (e.g., albedo, thickness, evaporation efficiency) and thermodynamic properties (e.g., heat capacity, thermal conductivity, emissivity) often differ greatly from natural surfaces (Oke, 1987). Consequently, these artificial surfaces and additional anthropogenic sources can alter the local energy balance. This combination of disruption to the local dynamics and energy balance has broad local and regional implications on meteorology and air quality.

The presence of an urban surface introduces further complexity to the flow in the surface layer of the ABL. The roughness sublayer (RSL) of the atmospheric surface layer can be broadly defined as a layer of strong vertical shear with non-uniform turbulent motions (e.g., wake eddies, plumes) scaled by the local roughness element height and interelement spacing (Rotach, 1999; Roth 2000; Arnfield, 2003). At the height where these turbulent motions become sufficiently well-blended and turbulent fluxes become constant with height the RSL is replaced by the inertial sublayer (Rotach, 1999; Roth 2000; Arnfield, 2003), which extends through the remaining depth of the surface layer. The RSL depth over vegetation typically varies from 0.5 to $50 \mathrm{~m}$ above the ground (Garratt, 1992) or approximately $2 \times z_{R}$ to 5 $\times z_{R}$ or more (Roth, 2000), where $z_{R}$ is the roughness element height. Over urban surfaces, where buildings frequently dominate the roughness elements and provoke larger turbulent eddies, the observed RSL depth can occupy the bulk of the surface layer (Rotach, 1999; Barlow and Coceal, 2009). The length scale and characteristics of turbulent motions can change between the inter-building space (urban canyon) and the region immediately above the rooftop, introducing a further subdivision known as the urban canopy layer (UCL) where the observed wind profile often described as exponential (Macdonald, 2000). In addition to element

Published by Copernicus Publications on behalf of the European Geosciences Union. 
height and inter-element distance, turbulent eddy characteristics within an urban RSL are also particularly sensitive to the element (building) orientation, dimension and density, collectively referred to as the urban "morphology" (Cheng and Castro, 2002).

The urban surface energy budget is sensitive to the morphology (Oke, 1981, 1982). Buildings can cast shadows, reducing the infiltration of direct short wave radiation into urban canyons, while potentially increasing diffuse radiation via reflection (Mills, 2004). Buildings can also reduce canyon wind speed, limiting the upward turbulent heat flux and canyon ventilation, rendering canopy morphology characteristics, such as the aspect ratio $(\mathrm{H}: \mathrm{W})$ an important influence on flux strength (Coutts et al., 2007). Large buildings can function as heat storage mechanisms (Kawai and Kanda, 2010), increasing daytime up-take and nighttime emission to the urban environment. Building emissions may also be considered part of an anthropogenic heat flux contribution to the energy budget (Nunez and Oke, 1977; Sailor, 2009), which can also include contributions from vehicular exhaust, industrial effluents and building ventilation.

The presence of vegetated surfaces in an urban environment can yield evapotranspiration, contributing to the turbulent latent heat flux component of the surface energy budget (Grimmond and Oke, 1999a). The magnitude of this contribution to the surface energy budget can be dramatically reduced, however, in the absence of sufficient moisture or irrigation (Grimmond and Oke, 2002; Christen and Vogt, 2004; Offerle et al., 2006a) and can vary substantially for isolated versus more densely spaced vegetation (Offerle et al., 2006b; Hagishima et al., 2007). The fraction covered by vegetation per unit surface area can dictate the signature of the local surface energy budget Grimmond and Oke, 2002; Kanda, 2007). For example, residential sites with abundant vegetation and low structural density can more closely emulate a rural surface energy budget than an urban one (Balogun et al., 2009). As the vegetation fraction increases in urban environments, the ratio of heat storage to net radiation decreases (Kanda, 2007; Pearlmutter et al., 2009) while a reduction of vegetation and soil water storage increases urban heat storage due to increased radiative trapping and impervious surfaces (Coutts et al., 2007). Uncertainty in the experimental understanding of the response of the surface energy budget to change in the coverage by vegetation is coupled with considerable uncertainty in the modeling parameterizations of urban turbulent latent heat flux (Best et al., 2006; Grimmond et al., 2010). Exclusion of vegetation in the modeling of an urban surface energy balance can be detrimental to model estimation of daytime turbulent sensible heat flux, net radiation and heat storage as well (Grimmond et al., 2010).

Early modeling work evaluated the UBL in one and twodimensional simulations, treating the urban surface as a rough-wall, (a.k.a, "slab", "sandbox" approach), (Myrup, 1969; Delage and Taylor, 1970; Vukovich, 1973; Bornstein, 1975). Current efforts to numerically model the UBL span a variety of approaches. Recent computational fluid dynamics (CFD) studies focus on simulating flow within the urban canyon or an idealized channel. Such CFD approaches include Direct Numerical Simulation (DNS): (Leonardi et al., 2003) Reynolds Averaged Navier-Stokes (RANS): (Kim and Baik, 1999) and Large-Eddy Simulation (LES): (Walton et al., 2002; Walton and Cheng, 2002). A viable compromise of computational efficiency and accuracy of dynamics and thermodynamics in the urban environment is the mesoscale NWP approach. Mesoscale models alone can only parameterize these processes in bulk subject to the scale of the surface land cover representation. Studies seeking to simulate the real urban environment through this approach often adopt an urban canopy model (UCM) or similar parameterizations (Masson, 2000; Kusaka et al., 2001; Martilli et al., 2002; Lee and Park, 2008; Miao et al., 2009). This study evaluates urban meteorology at the mesoscale using a single layer UCM coupled to a numerical weather prediction (NWP) model: the Weather Research and Forecasting (WRF) Advanced Research model v2.2 (WRF-ARW, see Sect. 2.1). The single layer UCM used here progresses toward a closer approximation of physical processes in the real urban environment versus the sandbox approach by estimating urban canyon wind speed, sky view factor, short and longwave radiation reflection and surface energy balance at the roof, wall and road facets of the urban canopy. Subsequent WRF model generations incorporate additional functionality for urban surface parameterization. Where sufficient morphology and building energy data is available for application, the Building Environment Parameterization (BEP; Martilli et al., 2002) option permits a multi-layer canopy model that can extend above the lowest model layer and the Building Energy Model (BEM; Salamanca and Martilli, 2009) can incorporate the effect of heating and cooling systems.

In balancing the computational expense of a large NWP model with the need for accuracy, of critical concern is the optimal scale for surface representation. This study investigates the nature of the error in the model meteorology that evolves specifically from a reduced scale of surface representation. The model examines a real urban area under fair weather conditions, concentrating on the response of the surface energy budget, temperature, turbulence kinetic energy, stability and near-surface flow. Section 2 outlines the model and methods adopted. Section 3 offers model verification. Section 4 outlines the principal results and analysis and Sect. 5 offers conclusions.

\section{Method}

\subsection{WRF-ARW model}

This study uses the Weather Research and Forecasting Model (WRF) Advanced Research (ARW) version 2.2 (Skamarock et al., 2007) to simulate the mesoscale 
meteorology. The model time integration uses a third-order Runge-Kutta scheme; horizontal advection of momentum and scalars uses a fifth-order scheme, third-order in the vertical. This study makes use of the model's Rayleigh damping term to stabilize vertical momentum when the vertical velocity approaches the Courant number for stability as well as a sixth-order numerical diffusion term in the horizontal momentum equations to filter short-wave numerical noise. Horizontal eddy viscosity is determined from the Smagorinsky first-order closure method (Smagorinsky, 1963). Two-way interactive nested grids are invoked, with a 4-grid point relaxation zone boundary condition.

This study selects the Mellor-Yamada-Janjic (MYJ) ABL scheme (Janjic, 2002) and accompanying Eta surface layer model to parameterize the ABL. Vegetation and other land surface processes are parameterized using the Noah land surface model (LSM) (Chen and Dudhia, 2001). Cloud microphysics is parameterized according to the WRF Single Moment 3-Class scheme (Hong et al., 2004). Cumulus cloud parameterization is applied only in the coarsest model grid (see Sect. 2.2) according to the Kain-Fritsch scheme (Kain, 2004; Kain and Fritsch, 1993). Longwave radiation is parameterized according to Rapid Radiative Transfer Model of Mlawer et al. (1997) and shortwave radiation according to Chou and Suarez (1994). Initial conditions are taken from NCEP Eta 212 grid (40 km) model analysis (a.k.a.,"AWIP”) data available from the University Corporation for Atmospheric Research (UCAR) in three-hour increments at 26 vertical levels from $1000 \mathrm{hPa}$ to $50 \mathrm{hPa}$. The AWIP data initializes the parent domain (see Sect. 2.2) and all nested grids at the start of model integration and provides boundary conditions for the parent domain.

To model the urban environment, WRF-ARW v2.2 provides a single layer urban canopy model (UCM) of Kusaka et al. (2001). This UCM represents urban areas as twodimensional street canyons of infinite length without specified street orientation, designed as an extension to the Noah LSM. The UCM balances all energy sources locally at the four-layer road, wall and roof surfaces of each model grid cell: the surface energy balance is calculated independently at each surface (roof, wall and road) by iteratively (NewtonRaphson) manipulating the local skin surface temperature to adjust the heat fluxes the sum is sufficiently close to zero and the skin surface temperature $\left(T_{\mathrm{S}}\right)$ and diagnostic mean canyon air temperature $\left(T_{\mathrm{c}}\right)$ are in steady-state. The contribution of heat flux from each surface is scaled according to the normalized length of the roof $(R)$, wall $(h)$ and road $\left(R_{\mathrm{W}}\right)$ where $R+R_{\mathrm{W}}=1$. The WRF preprocessor (WPS) assigns a single surface cover class to each grid cell according to the selected surface cover dataset (see Sect. 2.2). The LSM uses the corresponding class physical and thermodynamic parameters (e.g., albedo, emissivity, roughness length) to calculate the surface heat fluxes. In the case of a grid cell surface class defined as "urban" (in the dataset used there are four such classes: Sect. 2.2), the LSM defines the (total) grid cell heat flux from the surface as the sum of flux from artificial/anthropogenic surfaces (calculated from the UCM) and the natural surface (defined automatically as a "grassland" class), partitioned according to the grid cell fractional coverage by the artificial surface $\left(f_{\mathrm{URB}}\right)$, e.g., for sensible heat flux:

$$
H_{\text {total }}=f_{\mathrm{URB}} H_{\text {urban }}+\left(1-f_{\mathrm{URB}}\right) H_{\text {natural }}
$$

The single class surface cover assignment approach in mesoscale modeling can yield dissimilar flux estimates versus an approach that aggregates flux from sub-grid scale class fraction; the former is shown to be more sensitive to resolution change (Schlünzen and Katzfey, 2003). A diagnostic mean canyon wind speed is computed from an exponential function subject to the geometry of the canyon and speed of the flow above (Kusaka and Kimura, 2004). Further detail of the UCM and its coupling to WRF are presented by Kusaka et al. (2001) and Kusaka and Kimura (2004).

Some minor adjustments were made to the parameter settings for application to the Detroit-Windsor domain. The internal roof and wall temperature were set to $298.15 \mathrm{~K}$ to reflect a typical summertime mid-latitude interior building temperature (Walker, 2006). The internal road (ground) temperature was set to $295.25 \mathrm{~K}$ to reflect the approximate seasonal (JJA) average surface ( 2 ma.g.l.) temperature at Detroit-Windsor (National Weather ServiceDetroit/Pontiac, 2010). A four-class urban land surface type approach (Grimmond and Oke, 1999b) is used in place of the default three-class approach. Table 1 lists the principal gridded urban parameters by type, a blend of values recommended by Grimmond and Oke (1999) and morphological estimates from remote sensing imagery. The non-gridded urban parameters (e.g., surface albedo, thermal conductivity and surface emissivity, etc.) were selected following a review of common parameterizations in the literature for similar implementations (Lee and Park, 2008; Miao et al., 2006; Kusaka and Kimura, 2004; Martilli, 2002; Masson, 2000), in conjunction with default UCM values.

\subsection{Domain}

The area of interest is the Detroit-Windsor metropolitan area, estimated population: 4726779 (Statistics Canada, 2006; United States Census Bureau, 2010) straddling the USCanada border (Fig. 1). This urban area is located in the Great Lakes region of North America, an area of generally flat topography adjacent to multiple, large fresh water bodies. The Detroit River separates the cities of Detroit and Windsor and extends from Lake St. Clair in the east to Lake Erie in the south. The model domain consists of one parent grid, stretching across the contiguous US and southern Canada, and three telescopically nested grids $(\Delta x=37.5,7.5,1.5$ and $0.3 \mathrm{~km}$, respectively). Grid 1 extends across 140 (86) gridpoints from west to east (north to south); both grids 2 and 3 are of squares of 36 gridpoints per side and grid 4 is a square 
Table 1. Values assigned to gridded urban parameters in the WRF urban canopy model according to surface type.

\begin{tabular}{lrrrrrrr}
\hline $\begin{array}{l}\text { Urban } \\
\text { Surface Type } \\
\text { Classification }\end{array}$ & $\begin{array}{r}\text { Bldg. } \\
\text { Height } \\
(\mathrm{m})\end{array}$ & $\begin{array}{r}\text { Roughness } \\
\text { Length, } \\
\text { Disp. Height } \\
(\mathrm{m})\end{array}$ & $\begin{array}{r}\text { Norm. } \\
\text { Bldg. } \\
\text { (Road) } \\
\text { Width }\end{array}$ & $\begin{array}{r}\text { Norm. } \\
\text { Bldg. } \\
\text { Height }\end{array}$ & $\begin{array}{r}\text { Drag } \\
\text { Coeff. }\end{array}$ & $\begin{array}{r}\text { Bldg. } \\
\text { Volume } \\
\text { Parm. }\end{array}$ & $\begin{array}{r}\text { Urban } \\
\text { Fraction }\end{array}$ \\
\hline Open Space & 7 & $0.7,1.4$ & $0.50(0.50)$ & 0.337 & 0.037 & 0.28 & 0.10 \\
Low Intensity & 7 & $0.7,3$ & $0.50(0.50)$ & 0.337 & 0.053 & 0.28 & 0.35 \\
Medium Intensity & 10 & $1.0,6$ & $0.63(0.37)$ & 0.242 & 0.083 & 0.40 & 0.65 \\
High Intensity & 16 & $1.6,11$ & $0.81(0.19)$ & 0.190 & 0.123 & 0.64 & 0.90 \\
\hline
\end{tabular}
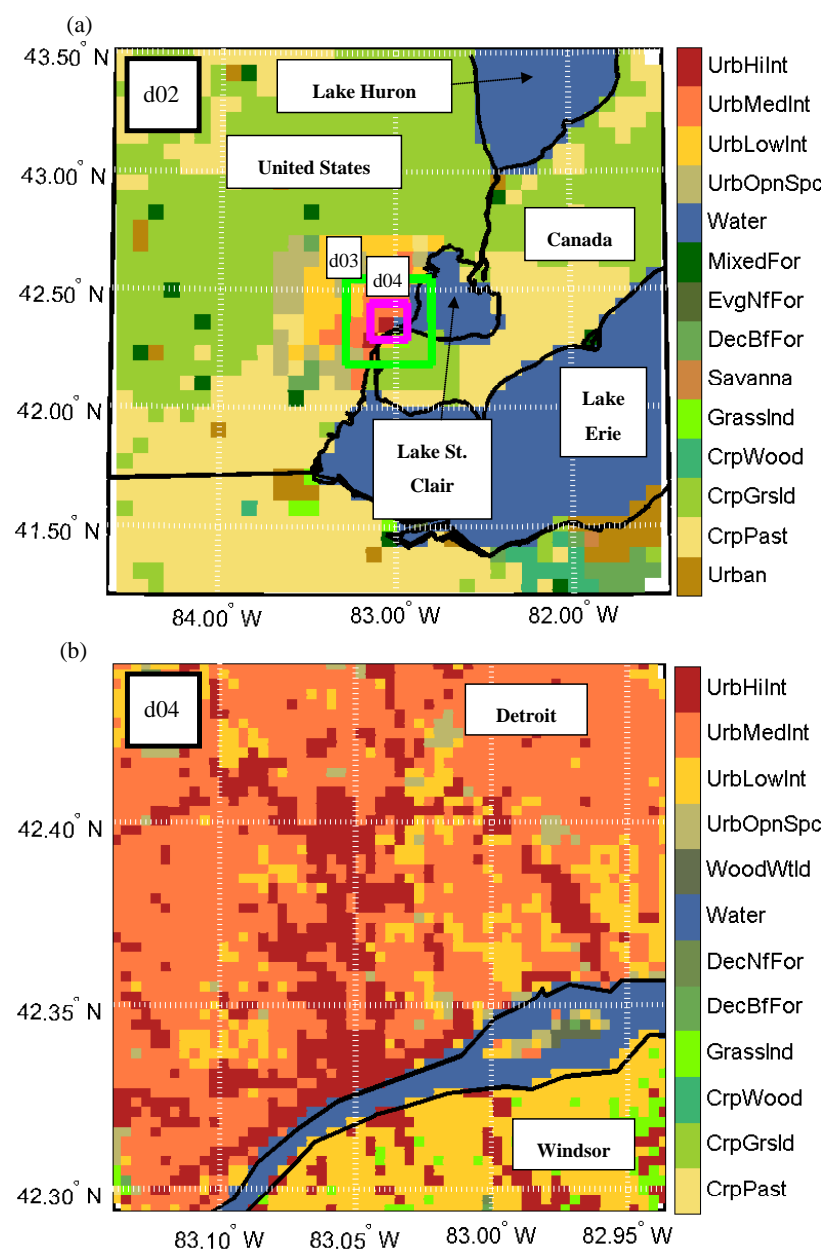

Fig. 1. Surface land cover type over the 2 nd (a) and 4 th (b) grids of the model domain over Detroit-Windsor (see Appendix A for abbreviations). Outlines of the 3rd grid (d03: green) and 4th grid (d04: magenta) appear in (a). The 1 st grid (d01, not shown), is centered at $42.26^{\circ} \mathrm{N}, 93.10^{\circ} \mathrm{W}$ and extends across approximately $64^{\circ}$ longitude and $29^{\circ}$ latitude.

of 66 gridpoints per side. The model was run with 59 vertical levels and set to have approximately 21 levels in the lowest kilometer.
The resolution of the innermost grid (d04) approaches the limit of viability for application of the MYJ scheme to represent ABL turbulence; the scale of some eddies in the afternoon well-mixed layer in cases examined here likely briefly exceed the d04 grid scale. However, model TKE damping at the highest resolutions (energy cascade compensation) leads to an effective model resolution of approximately $7 \Delta x$ (Skamarock, 2004), or approximately $2.1 \mathrm{~km}$ in $\mathrm{d} 04$ here. This scale exceeds $h_{\mathrm{ABL}}$ throughout the d04 grid in the test cases examined here. In addition, Miao et al. (2009) demonstrate successful implementation of the MYJ ABL scheme in WRF at similarly high resolution $(0.5 \mathrm{~km})$ under fair-weather, warm-season conditions using the single layer UCM with comparable vertical resolution. Similarly, Gutiérrez et al. (2010) and Salamanca et al. (2010) indicate success with a $0.333 \mathrm{~km}$ grid scale using the BougeaultLacarrère (BouLac) ABL scheme (Bougeault and Lacarrère, 1989) with WRF, a TKE-prediction scheme like MYJ.

To create a high-resolution four-class urban land surface type dataset, the international border bisecting the domain necessitated a splice of three sources of land surface type data. These sets included the USGS National Land Cover Dataset (NLCD 2001), the NOAA Coastal Resources Center (CRC) Land Use Dataset and the Ontario Ministry of Natural Resources (MNR) Land Cover dataset. The USGS NLCD (2001) set consists of a raster image of Albers Equal Area Conical projection with 22 land surface type categories equally spaced at a resolution of one arc-second. Among the 22 land use categories are four designed to characterize the urban surface: (1) developed, open space, (2) developed, low intensity, (3) developed, medium intensity and (4) developed high intensity, in order of increasing density of structures and of anthropogenic influence on the surface. These categorical surface classifications are selected for the fourclass scheme used here; the morphological differences can be found in Table 1. The NOAA CRC data is of identical projection and resolution to USGS NLCD (2001), but distinguishes only two categories of urban surface (low and high intensity). The NOAA CRC data covers the Lake St. Clair watershed, covering approximately $20-25 \mathrm{~km}$ inland of the lake shore, including the city of Windsor. The MNR data is 
a raster image of Lambert Conformal Conic projection with 28 land surface types and pixels evenly spaced in intervals of $25 \mathrm{~m}$ available with geo-reference coordinates. Of the 28 land surface types, one is reserved for classification of urbanized surfaces. To create a common set of land surface types, the MNR categories were mapped to the corresponding USGS categories with the MNR urban type assigned to the developed, medium intensity category. The MNR data covers all land surfaces within Ontario.

The USGS NLCD (2001), NOAA CRC and MNR datasets were spliced together using GIS algorithms and software. To enable tests of systematically varying land surface resolution, the sets were gridded into intervals of 10, 20, 30, 60 and 120 arc-seconds in separate procedures. In regions of resource data overlap, all three resources contributed equally to the categorical assignment of each grid cell. An exception is made for those cells classified as urban surface, in which case classification was left to the mode classification of the USGS NLCD (2001) dataset over Detroit and the NOAA CRC dataset over Windsor. The resulting five blended, gridded land surface datasets are raster images of uniformly spaced pixels with categorical assignments to one of the 33 land surface types defined by the USGS NLCD (2001). Remote sensing imagery provided verification of the land surface raster images.

\subsection{Case studies}

The five gridded raster images of the Detroit-Windsor metropolitan area described above provide a source to understand how change in the representation of the urban surface under a common model resolution manifests through the model-estimated meteorology. This study runs five test cases, distinguished only by the scale of surface representation in arc-seconds (s): 10, 20, 30, 60 and 120; model resolution is held constant.

The finest resolution case $(10 \mathrm{~s})$ was chosen to reflect the "neighborhood" scale $O\left(10^{2} \mathrm{~m}\right)$, capable of capturing the mean geometric and thermodynamic properties of a particular urban neighborhood without the need to explicitly resolve individual buildings or street canyons, as would likely be necessary at finer resolutions. Model estimates from case $10 \mathrm{~s}$ runs represent the model's best-guess for simulation of the meteorology. Departure from these model estimates in coarser case runs represents sensitivity to the scale of representation of the surface. In lieu of sufficient verification at this site, statistical analyses provide a measure of the model sensitivity to surface cover resolution and can permit some understanding of how overall model performance changes.

Analysis is mostly limited to the fourth model grid (Fig. 1), concentrating on two periods within the Border Air Quality and Meteorology Study (BAQS-Met) 2007 field campaign: 12:00 UTC 23 June - 12:00 UTC 25 June 2007 (Period 1) and 00:00 UTC 7 July-00:00 UTC 8 July 2007 (Period 2), with the first six-hour Period withheld from analysis to allow for model spin-up time. For both periods, local time in DetroitWindsor is (UTC-4) hours. The surface water temperature is held constant according to initial conditions throughout the duration of the model integrations. The two periods provide a useful archive for response under varying wind speed and direction. Both periods are dry and generally cloudfree over the analysis area, dominated by synoptic-scale high pressure (1016-1019hPa). In Period 1, nearly calm winds on 23 June yield to increasing south-southeast flow late on 24 June. Low-level winds gradually veer to southwest after 00:00 UTC 25 June as high and mid-level cloud cover increase gradually ahead of a weak extratropical cyclone. In Period 2, morning low-level wind speeds are nearly calm, increasing to $2-5 \mathrm{~ms}^{-1}$ from the southwest by afternoon.

\section{Model verification}

To test the validity of model estimates in the urban boundary layer, a thorough verification of the model configuration is necessary. The BAQSMet 2007 field campaign included a series of flights by a Twin Otter aircraft measuring meteorological and chemical quantities at various heights across southwestern Ontario and adjacent areas around Detroit. The Twin Otter datasets serve as the crux of model verification data in the Detroit-Windsor domain, supported with additional data from radiosondes, METAR and a VHF wind profiler.

To complement this verification with a more precise diagnosis of model performance within and above the urban canopy, additional model comparison studies were conducted over Oklahoma City, OK, USA (omitted here). These comparison studies utilized measurements from the Joint Urban 2003 field campaign (Allwine et al., 2004) to verify model estimates.

\subsection{Instrumentation}

BAQS-Met 2007 field data includes a series of measurements taken on-board the National Research Council (NRC) Twin Otter Atmospheric Research Aircraft (hereinafter: Twin Otter). Instrumentation aboard included an array of air sampling equipment and meteorological instruments (Srinivasan and Bastian, 2008). Two flights crossed the urban core grid of the domain and are used here for model verification: Flight \#12 (3-4 July 2007) and Flight \#13 (6-7 July 2007). Measurements of three-dimensional wind, temperature $(T)$, dew point temperature $\left(T_{\mathrm{d}}\right)$ and air pressure $(p)$ were extracted for model verification.

Several additional stationary sources supplement Twin Otter data toward model verification. Radiosonde launches (with GPS) by the US National Weather Service (NWS) at White Lake, Michigan, (KDTX: $42.70^{\circ} \mathrm{N}$, $83.47^{\circ} \mathrm{W}$ ) provide a useful comparison for temperature, water vapor mixing ratio $(q)$, wind speed $(|\vec{u}|)$ and wind direction $\left(\vec{u}_{\theta}\right)$. This station is located within the second grid 
of the model domain, west of Detroit-Windsor. Profiles are extracted from the launch times nearest to Flights \#12 and \#13. During Twin Otter Flight \#13, three missed landings took place at airports with hourly Avaiation Routine Weather Reports (METAR) available from in situ instruments at field level (Plymouth State University, 2010), two of which coincide within several minutes of METAR data, providing points of surface verification.

A VHF wind profiler installation at Harrow, $\mathrm{ON}\left(42^{\circ} 42^{\prime} \mathrm{N}\right.$ $83^{\circ} 28^{\prime} \mathrm{W}$ ), part of the Ontario-Quebec VHF Wind Profiler Network (Hocking and Hocking, 2007), provides hourly horizontal wind speed and direction measurements in $500 \mathrm{~m}$ range gates throughout much of the troposphere. Data is available for comparison during both study periods when and where sufficient signal return is present, but no data is available during Flight \#12. The wind profiler is situated in the second model grid, approximately $50 \mathrm{~km}$ south-southeast of the urban core of Detroit-Windsor (Fig. 2).

\subsection{Data quality control}

Measurement of the true air velocity on-board the Twin Otter is subject to uncertainty caused by the blending of instrumentation to produce the final dataset (Srinivasan and Bastian, 2008). A correction was made to compensate for a systematic horizontal wind error for the two flights examined here (K. Hayden, Environment Canada, personal communication, 2009). To reduce bias in vertical velocity measurements, the $1 \mathrm{~Hz}$ instantaneous moments of vertical velocity were detrended by removing the mean vertical velocity.

To mitigate white noise in these datasets of $1 \mathrm{~Hz}$ sampling frequency, a one-minute average was taken for all variables. This averaging Period was selected to facilitate modelmeasurement comparison; model estimates were archived in one-minute sampling intervals (instantaneous) for the duration of each flight. The $1 \mathrm{~Hz}$ data was retained for the calculation of turbulence kinetic energy (TKE) per unit mass.

To verify model estimates, this study uses a 16-point linear interpolation algorithm to map model estimates to observation space (Eq. 2). Given an observed variable $y$ at $y\left(i_{0}, j_{0}, k_{0}, l_{0}\right)$ where $i_{0}$ and $j_{0}$ reflect the horizontal position, $k_{0}$ the vertical position and $l_{0}$ the temporal position, the algorithm seeks the nearest model estimates of the model variable $x$, which may be a variable identical to $y$ or in need of conversion (e.g., dew point temperature to mixing ratio). The algorithm extracts $x$ at the four model grid points surrounding $y\left(i_{0}, j_{0}, k_{0}, l_{0}\right)$ in horizontal, two-dimensional space at the two model vertical levels that enclose the height of the observation $\left(k_{0}\right)$. The algorithm then extracts these eight points at the two model output times that enclose the observation time $\left(l_{0}\right)$. The algorithm then interpolates the model variable to the point of observation, $\widehat{x}\left(i_{0}, j_{0}, k_{0}, l_{0}\right)$, by applying weights to $x$ at the 16 grid points determined earlier. The weights are inversely proportional to the three-dimensional (a)

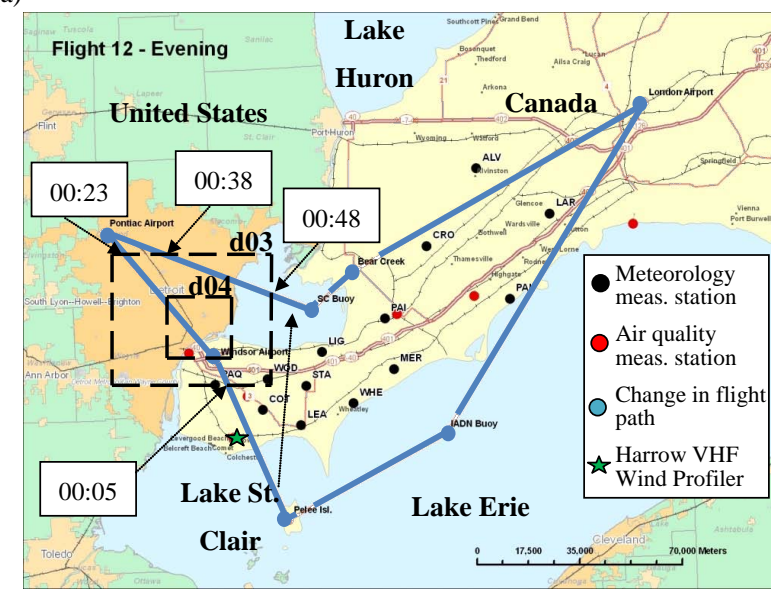

(b)

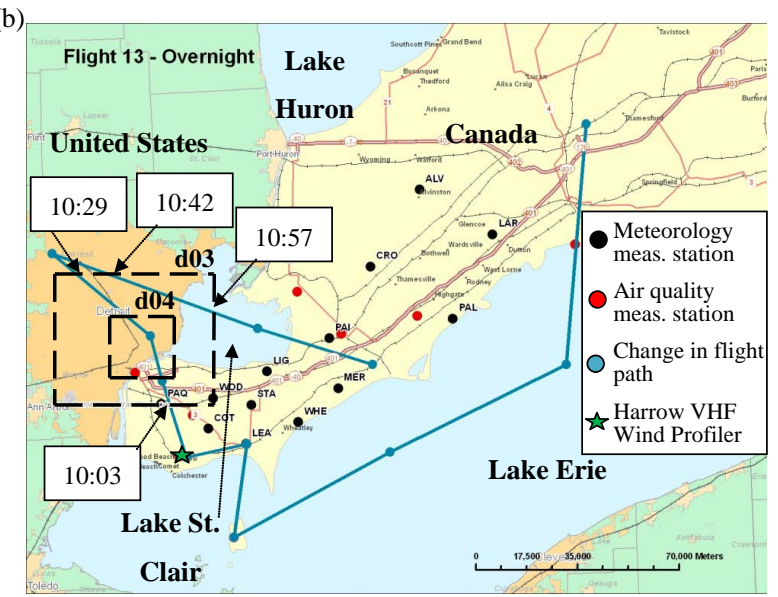

Fig. 2. The approximate flight paths of Flight \#12 (a) and \#13 (b) during BAQS-Met 2007, depicted by the blue line. The third (d03) and fourth (d04) model grid domains are outlined in dashed black lines with boxes indicating the approximate UTC time (4 July 2007 (a), 7 July 2007 (b)) upon entering and exiting the d03 domain. Adapted with permission from a figure by Julie Narayan, Environment Canada.

distance $(d)$ or time $(t)$ between the model grid point and the observation according to Eq. (2)

$\widehat{x}\left(i_{0}, j_{0}, k_{0}, l_{0}\right)=\sum_{m=1}^{2}\left(\frac{\frac{1}{t_{m}}}{\sum_{m=1}^{2} \frac{1}{t_{m}}}\right) \sum_{n=1}^{8} x_{n}\left(i_{n}, j_{n}, k_{n}, l_{n}\right) \cdot\left(\frac{\frac{1}{d_{n}}}{\sum_{n=1}^{8} \frac{1}{d_{n}}}\right)$ (2)

On the basis of the high resolution of the gridded model data in the region of verification (generally near the surface), error associated with the linear interpolation of model estimates is assumed to be significantly smaller than the resulting model biases (see Sects. 3.3, 3.4). 
Table 2. RMSE (top) and mean bias (bottom) of model estimates for selected variables vs. verification datasets including aircraft data (T. O. = "Twin Otter"), radiosonde (KDTX) and a VHF wind profiler (Harrow Profiler).

\begin{tabular}{lrrrrr}
\hline RMSE & Temp. & $\begin{array}{r}\text { Water Vapor } \\
\text { Mixing Ratio } \\
\left(\mathrm{g} \mathrm{kg}^{-1}\right)\end{array}$ & $\begin{array}{r}\text { Horiz. Wind } \\
\text { Speed } \\
\left(\mathrm{m} \mathrm{s}^{-1}\right)\end{array}$ & $\begin{array}{r}\text { Horiz. Wind } \\
\text { Direction } \\
\left({ }^{\circ}\right)\end{array}$ & $\begin{array}{r}\text { Comparison } \\
\text { Points }\end{array}$ \\
& $(\mathrm{K})$ & 2.58 & 2.48 & 105.46 & 30 \\
\hline T.O. Flgt \#12 (3-4 July) & 2.71 & 5.44 & 2.11 & 47.53 & 43 \\
T.O. Flgt \#13 (6-7 July) & 3.01 & 0.71 & 2.84 & 7.79 & 65 \\
KDTX (00:00 UTC 4 July) & 3.77 & 0.70 & 2.96 & 18.98 & 58 \\
KDTX (12:00 UTC 7 July) & 4.01 & $\mathrm{tn} / \mathrm{a}$ & 1.92 & 25.33 & 270 \\
Harrow Profiler (7 July) & $\mathrm{n} / \mathrm{a}$ & & & & \\
\hline Bias & & & & & \\
\hline T.O. Flgt \#12 (3-4 July) & -2.52 & -2.55 & 1.91 & 100.70 & 30 \\
T.O. Flgt \#13 (6-7 July) & -2.83 & -4.90 & 1.61 & -6.05 & 43 \\
KDTX (00:00 UTC 4 July) & 2.43 & -0.06 & 0.87 & -3.05 & 65 \\
KDTX (12:00 UTC 7 July) & 2.14 & 0.38 & 1.40 & -12.67 & 58 \\
Harrow Profiler (7 July) & $\mathrm{n} / \mathrm{a}$ & $\mathrm{n} / \mathrm{a}$ & -0.36 & 3.02 & 270 \\
\hline
\end{tabular}

(a)

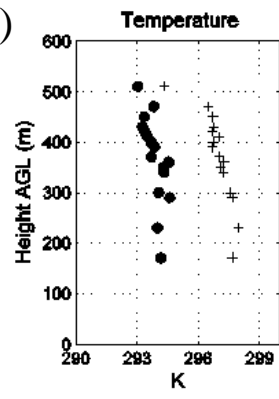

(b)

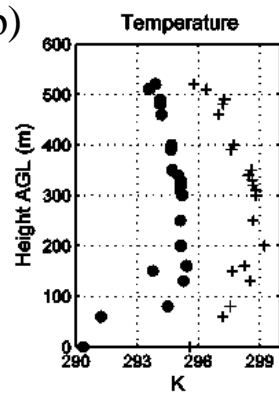

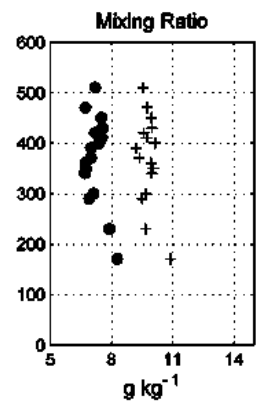
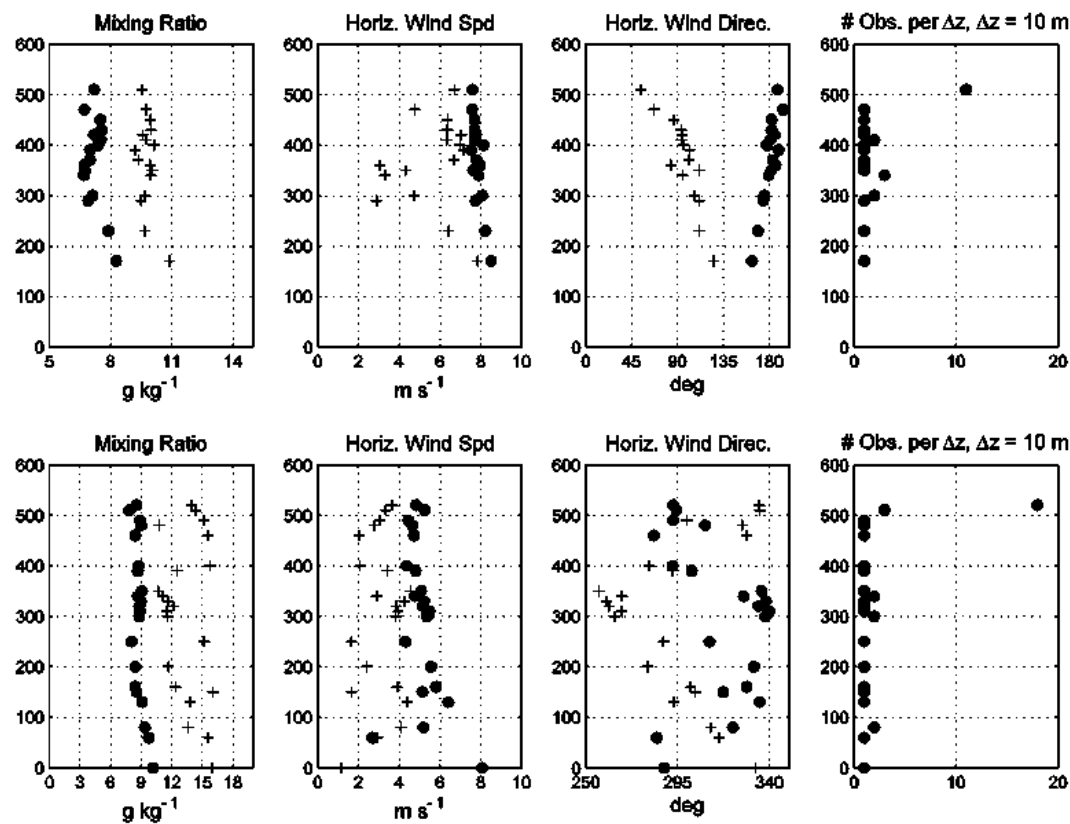

\# Obs. per $\Delta z, \Delta z=10 \mathrm{~m}$
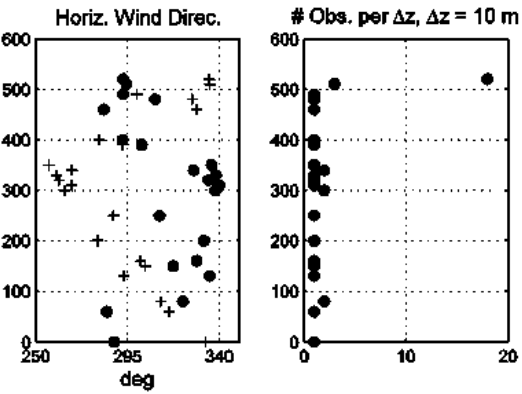

Fig. 3. Model verification versus height using Twin Otter Flight \#12 (3-4 July 2007, (a)) and Flight \#13 (6-7 July 2007, (b)) measurements intercepting the third model grid. Variables depicted include: temperature, water vapor mixing ratio, scalar-average horizontal wind speed and horizontal wind direction. Model estimates are interpolated to observations and both are organized into $10 \mathrm{~m}$ bins. Each column shows the (bin-averaged) observed values (+) and model estimates (circles). The number of comparison points contributing to each bin is shown at the far right.

\subsection{Flight \#12}

BAQS-Met 2007 Twin Otter Flight \#12 crossed through the third grid of the model domain between 00:05 and 00:48 UTC 4 July 2007, exiting the northwest corner of the domain for $15 \mathrm{~min}$ within that Period for a course change at Oakland International Airport (KTPK) in Pontiac, Michi- gan, USA (Fig. 2a). Within the third model grid, the flight level varies between roughly 300 to $500 \mathrm{~m}$ a.g.l., except in the final minutes when the aircraft descends to approximately $170 \mathrm{~m}$ a.g.l.

A majority of measurements are clustered near $510 \mathrm{~m}$ a.g.l. (Fig. 3). Comparison indicates a cold model bias in air temperature (Table 2), though this bias is noticeably smaller 
(a)

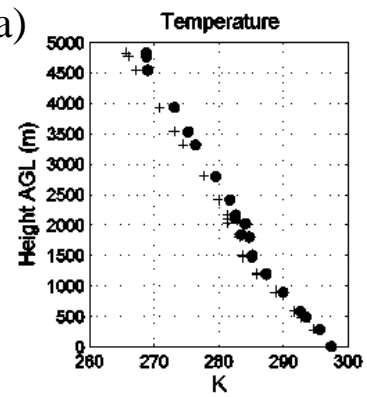

(b)

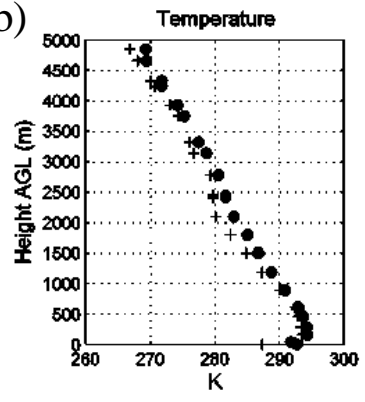

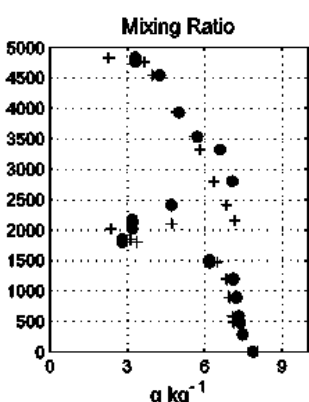

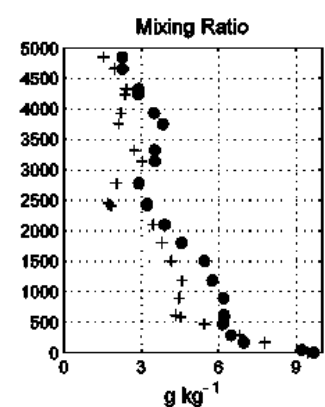

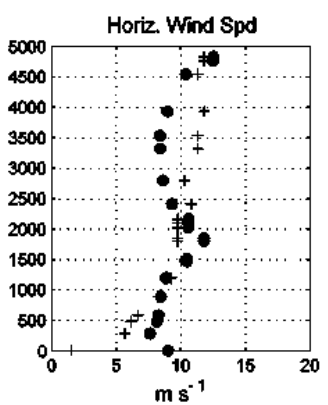
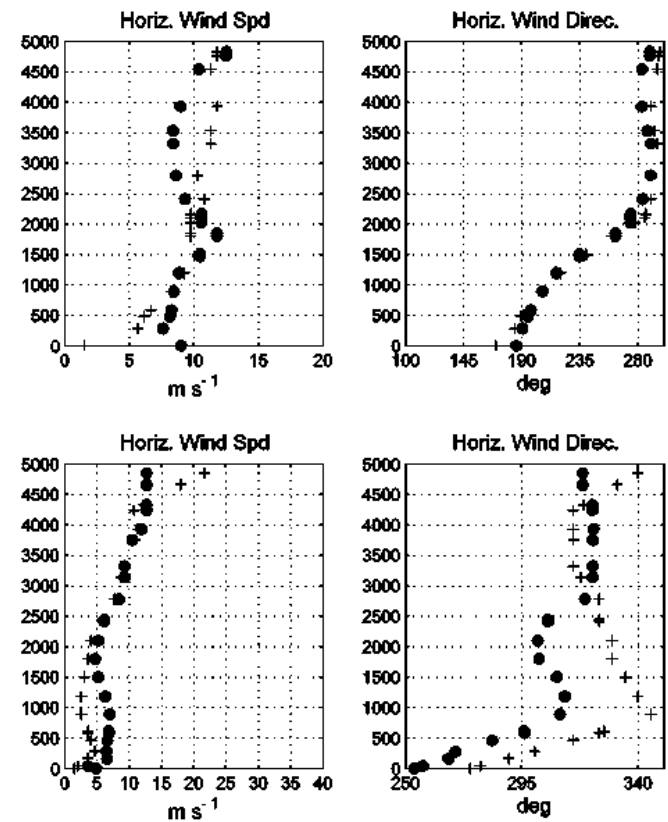

Fig. 4. Model verification versus height using radiosonde measurements of temperature, water vapor mixing ratio, scalar average horizontal wind speed and horizontal wind direction in the lowest $5 \mathrm{~km}$ at KDTX (42 $\left.42^{\prime} \mathrm{N} 83^{\circ} 28^{\prime} \mathrm{W}\right) 00 \mathrm{Z} 4$ July 2007 (a) and $12 \mathrm{Z} 7 \mathrm{July} 2007$ (b). Model estimates are interpolated to observations and both are organized into $10 \mathrm{~m}$ bins. Each column shows the (bin-averaged) observed values (+) and model estimates (circles).

where Twin Otter data is most abundant. Mamrosh et al. (2002) report a mean bias of around $+1 \mathrm{~K}$ for commercial aircraft (ACARS) measurements versus adjacent radiosonde measurements (within $10 \mathrm{~km}$ ), below $400 \mathrm{hPa}$. Ballish and Kumar (2008) find a bias of +0.6 to $1.5 \mathrm{~K}$ at $925 \mathrm{hPa}$ using AMDAR data, which is roughly 20 to $40 \mathrm{hPa}$ above most flight measurements here. Although instrumentation differs among these comparisons, this may partly explain the cold model bias. Comparing against 00Z 04 July 2007 radiosonde data (Fig. 4), model estimates overestimate temperature by $1-2 \mathrm{~K}$ in the lowest $2 \mathrm{~km}$, and by $\sim 2 \mathrm{~K}$ above that.

There is also a significant dry model bias (around $-2.5 \mathrm{~g} \mathrm{~kg}^{-1}$ ) relative to Twin Otter measurements (Table 2) that appears to be insensitive to height. This dry bias is not present in model comparison to the radiosonde data. Mamrosh et al. (2002) indicate a mean dew point temperature bias of approximately $+1.8 \mathrm{~K}$ among ACARS data. The presence of a similar moist bias, versus the true atmospheric state, in the Twin Otter measurements would suggest that model estimates are much closer to the true atmospheric state than suggested by this verification, though quantitative measurement error from these Twin Otter observations was unavailable.

Model performance with wind estimation is less clear; the model consistently overestimates scalar-average horizontal wind speed versus Twin Otter measurements. Comparison with radiosonde data suggests model overestimation below the model-estimated boundary layer depth $\left(h_{\mathrm{ABL}} \sim 939 \mathrm{~m}\right)$, with varying performance above. Wind direction also shows discrepancy versus Twin Otter measurements. Some of this can be explained by the relatively light wind speeds. This discrepancy, together with an unexplained backing of the winds, leaves some uncertainty in the Twin Otter wind measurements. Model estimated wind direction shows strong coherence with the 00Z 4 July 2007 radiosonde data (Fig. 4), with a model RMSE of $7.79^{\circ}$ for the full profile (Table 2). Model estimated TKE shows fairly strong coherence with observations, including a local peak near $400 \mathrm{~m}$ a.g.l. (not shown).

Examining model performance versus time (Fig. 5), Twin Otter temperature measurements during an ascent near 00:12 UTC 4 July suggest a highly unstable local lapse rate of $13 \mathrm{~K} \mathrm{~km}^{-1}$, not captured by the model. This observed feature is not replicated during the subsequent descent (00:3700:48 UTC), whereas the model response is proportionally opposite. Similar behavior is shown for wind speed with Twin Otter measurements indicating steadily increasing wind speed during ascent. The horizontal wind speed shows the strongest coherence of model and measurement directly over downtown Detroit, at $510 \mathrm{~m}$ a.g.l. Comparison of wind speed to 00:00 UTC METAR at Windsor Airport (CYQG: $\left.42.27^{\circ} \mathrm{N}, 82.97^{\circ} \mathrm{W}\right)$ reveals surface $(10 \mathrm{~m}$ a.g.l. $)$ winds of less than $2.5 \mathrm{~ms}^{-1}$, justifying the Twin Otter measurements. For wind direction, Twin Otter measurements suggest erratic change over short distances and largely differ from 
(a)
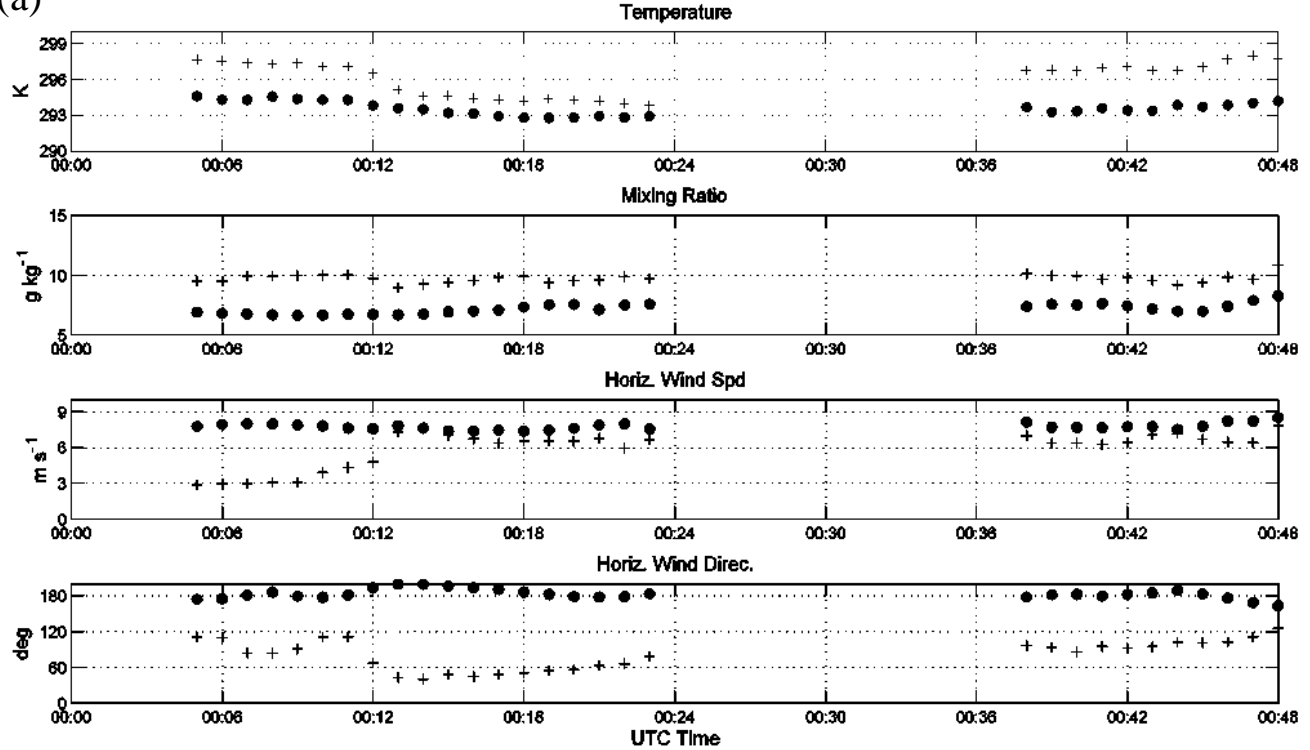

(b)
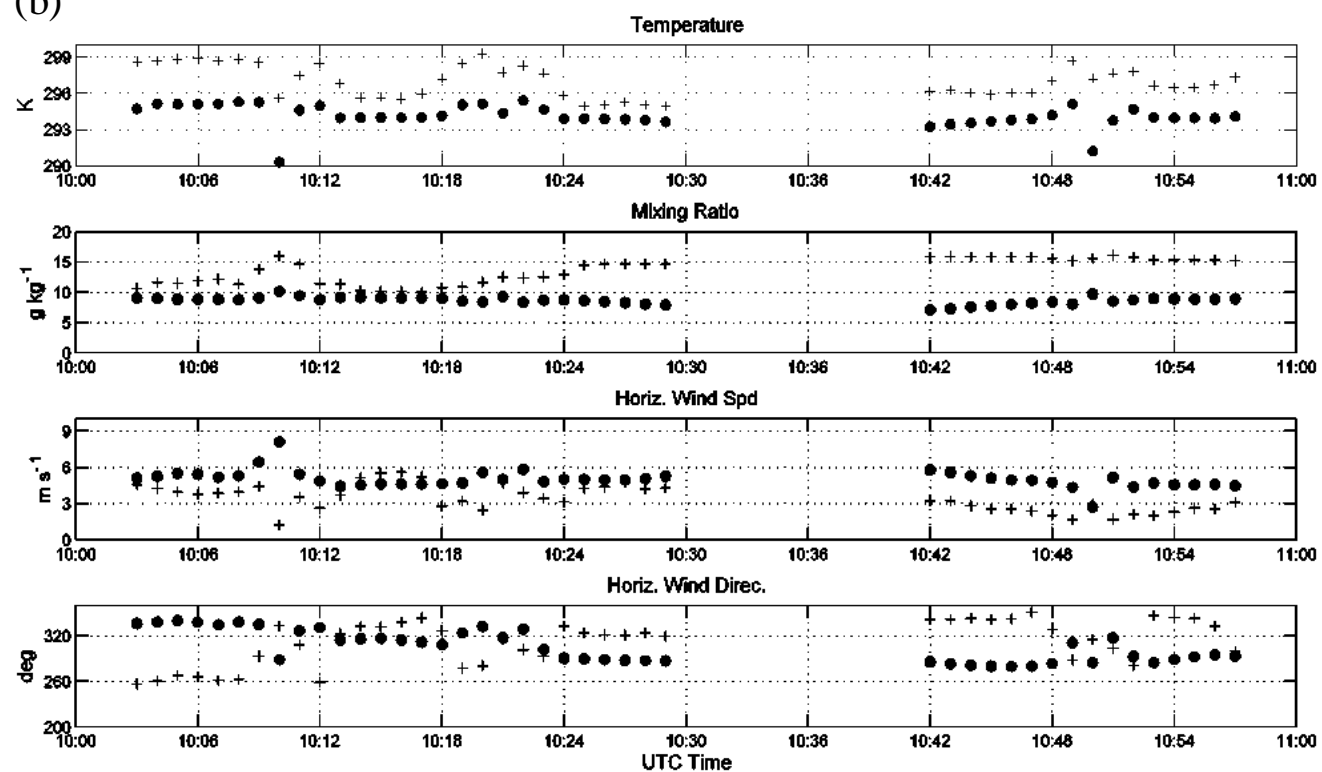

Fig. 5. Model verification versus time using Twin Otter Flight \#12 (3-4 July 2007, (a)) and Flight \#13 (6-7 July 2007, (b)) measurements intercepting the third model grid. Variables depicted include: temperature, water vapor mixing ratio, scalar-average horizontal wind speed and direction. Model estimates are interpolated to observations and both are organized into 1 min bins. Each row shows the (bin-averaged) observed values (+) and model estimates (circles).

METAR at CYQG (south at 00:00 UTC, south-southwest at 01:00 UTC) and Coleman A. Young International Airport (KDET: $42.42^{\circ} \mathrm{N}, 83.02^{\circ} \mathrm{W}$, south-southeast at both 00:00 and 01:00 UTC). These METAR wind directions match very well with model estimated wind direction.

\subsection{Flight \#13}

BAQS-Met 2007 Twin Otter Flight \#13 crossed the third grid of the model domain between 10:03 and 10:57 UTC 7 July 2007, exiting the northwest corner of the domain for $13 \mathrm{~min}$ near the middle for a course change at KPTK (Fig. 2b). Within the third model grid, the flight level varies across the lowest $520 \mathrm{~m}$ a.g.l., including three missed landings at 
Table 3. Measurements and model estimates for two missed landing maneuvers during Twin Otter Flight \#13, 7 July 2007. Airport measurements (CYQG, KDET) are taken from METAR, with scalar quantities measured at $2 \mathrm{~m}$ a.g.l. and wind measured at $10 \mathrm{~m}$ a.g.1. The height of Twin Otter measurements is a 1-min average. Model estimates are interpolated to the averaged Twin otter measurement height.

\begin{tabular}{lrrrrrr}
\hline & \multicolumn{3}{c}{ Missed Landing: 10:10 UTC } & \multicolumn{3}{c}{ Missed Landing: 10:50 UTC } \\
\cline { 2 - 7 } & $\begin{array}{r}\text { CYQG } \\
(10: 00)\end{array}$ & $\begin{array}{r}\text { Twin Otter } \\
(10: 10)\end{array}$ & $\begin{array}{r}\text { Model } \\
(10: 10)\end{array}$ & $\begin{array}{r}\text { KDET } \\
(10: 53)\end{array}$ & $\begin{array}{r}\text { Twin Otter } \\
(10: 50)\end{array}$ & $\begin{array}{r}\text { Model } \\
(10: 50)\end{array}$ \\
\hline $\begin{array}{l}\text { Measurement Hgt } \\
\text { (a.g.1.) }\end{array}$ & $2,10 \mathrm{~m}$ & $8 \mathrm{~m}$ & & $2,10 \mathrm{~m}$ & $68 \mathrm{~m}$ & \\
$\begin{array}{l}\text { Temperature } \\
(\mathrm{K})\end{array}$ & 292.2 & 295.6 & 290.3 & 291.5 & 297.2 & 291.1 \\
$\begin{array}{l}\text { Mixing ratio } \\
\left(\mathrm{g} \mathrm{kg}^{-1}\right)\end{array}$ & 10.2 & 15.9 & 10.2 & 10.2 & 15.6 & 9.7 \\
$\begin{array}{l}\text { Horiz. wind speed } \\
\left(\mathrm{m} \mathrm{s}^{-1}\right)\end{array}$ & 1.5 & 1.2 & 7.3 & 1.5 & 2.9 & 2.8 \\
$\begin{array}{l}\text { Wind direction } \\
\left({ }^{\circ}\right)\end{array}$ & 290 & 333 & 287 & 290 & 315 & 286 \\
\hline
\end{tabular}

airports within the model grid (10:10, 10:21, 10:50 UTC). Being an early morning transect, measurement points fall above the model estimated $h_{\mathrm{ABL}}(<200 \mathrm{~m}$ a.g.l. throughout the period) except for the missed landings.

The vertical comparison (Fig. 3) confirms the cold and dry model bias seen in Flight \#12, though both indicate a strong low-level temperature inversion. A model warm bias aloft versus radiosonde data is apparent. However, the radiosonde may drift horizontally up to $300 \mathrm{~km}$ during a typical two-hour ascent (NOAA National Weather Service, 2010).

A model dry bias versus Twin Otter measurements is present, as in Flight \#12. Whereas model estimates suggest a generally uniform water vapor mixing ratio, Twin Otter measurements indicate significant fluctuation, varying by as much as $6 \mathrm{~g} \mathrm{~kg}^{-1}$ in the lowest $500 \mathrm{~m}$ a.g.l. (Fig. 3). This observed variation cannot be wholly explained by the flight path over Lake St. Clair, sudden wind shifts or any recent rainfall. There is a much stronger coherence of model estimates to radiosonde water vapor mixing ratio measurements, with RMSE under $1 \mathrm{~g} \mathrm{~kg}^{-1}$ and smaller mean bias. During the course of radiosonde ascent, model estimated $h_{\mathrm{ABL}}$ increases from 250 to $350 \mathrm{~m}$ a.g.l., suggesting that the model overestimation of mixing ratio may be sensitive to the $h_{\mathrm{ABL}}$ estimate (Fig. 4). Turner et al. (2003) report a dry bias of approximately five percent in their studies using the Vaisala RS80-H radiosonde (commonly used by NWS) with a general 5-10 percent difference in relative humidity measurements from a dual-launch of radiosondes. Miller et al. (1999) report a systematic dry bias in radiosonde measurements of relative humidity in comparison to both surface stations and aircraft measurements in the mixed layer. Thus, the model moist bias may be partly explained by a potential radiosonde measurement error.
The model overestimates scalar-average horizontal wind speed comparing against both Twin Otter and radiosonde measurements (Figs. 3 and 4), with an RMSE of $2-3 \mathrm{~m} \mathrm{~s}^{-1}$. Comparison versus the Harrow VHF wind profiler for 7 July, with a relative abundance of model-measurement comparison points, yields a similar RMSE but with an improved mean bias that suggests a slight model underestimation (Fig. 6). Thus, bias in the model estimation of horizontal wind speed remains uncertain, but at least some local overestimation is likely present. Limited surface measurements from the Twin Otter missed landings also support model overestimation (Table 3).

Model RMSE of wind direction versus radiosonde and wind profiler measurements shows much less variability than that of Twin Otter measurements. Model estimates reasonably capture the profile of wind direction versus Harrow measurements (Fig. 6) for both 7 July (Period 2) and Period 1. At both missed landings shown in Table 3, model estimated wind direction and METAR wind match very well, while Twin Otter measurements show noticeable departure.

Evaluating the model performance versus time (Fig. 5), both missed landings at KDET show a pronounced spike in Twin Otter measured temperature not captured in the model. This may be due to interpolation of near surface temperature from local skin surface temperature and lowest vertical layer air temperature, potentially missing microscale variation. Though limited in number, model estimates are closer to METAR temperature than are the Twin Otter measurements (Table 3). The Twin Otter measures a sharp spike in mixing ratio at the CYQG missed landing (10:10 UTC), but not at either KDET missed landing, (10:21, 10:50 UTC) and shows a substantial increase in water vapor mixing ratio to the northwest, all absent from the model estimates. 
(a)
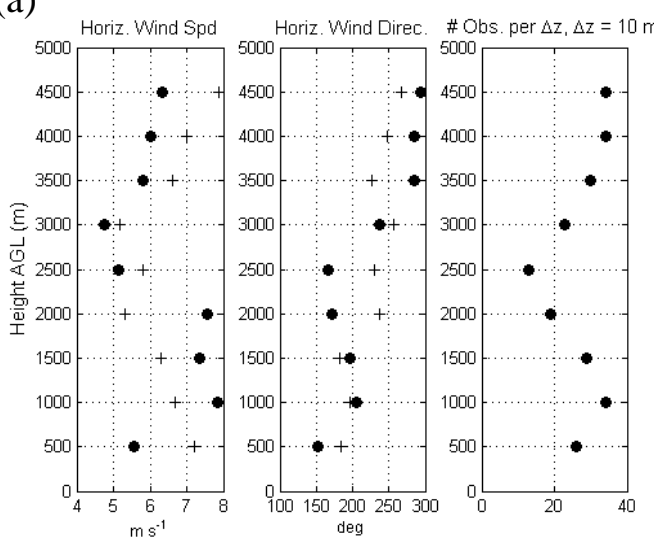

(c)
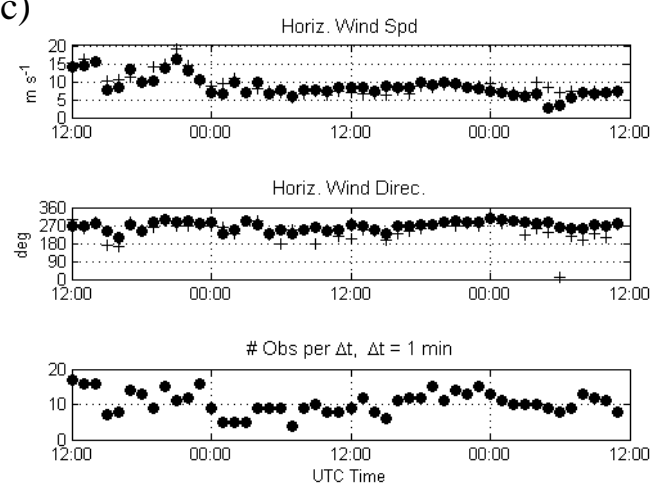

(b)

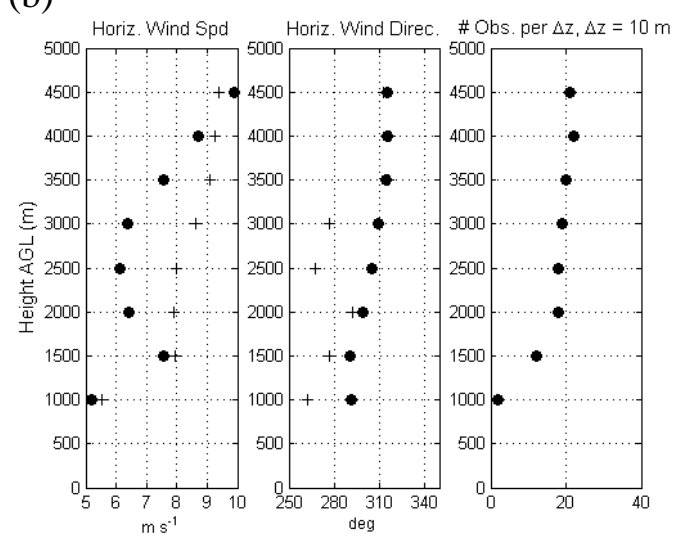

(d)
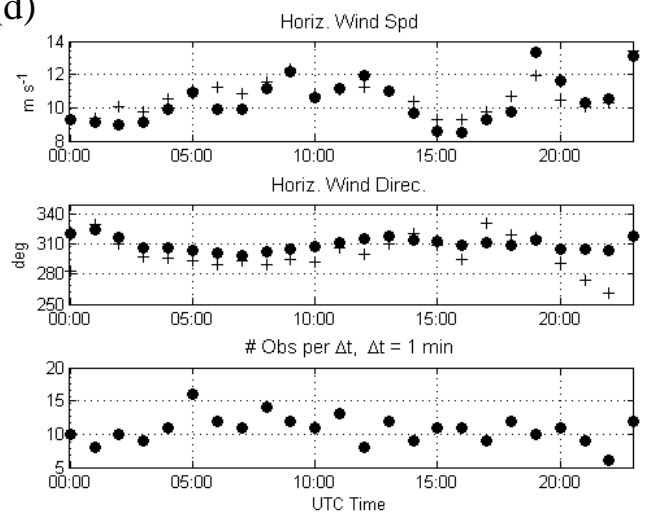

Fig. 6. Model verification versus height $(\mathbf{a}, \mathbf{b})$ and time $(\mathbf{c}, \mathbf{d})$ using VHF wind profiler measurements of horizontal wind speed and direction. The wind profiler is located at Harrow, $\mathrm{ON}\left(42^{\circ} 42^{\prime} \mathrm{N} 83^{\circ} 28^{\prime} \mathrm{W}\right)$. Model estimates are interpolated to observations which are hourly mean values for the $500 \mathrm{~m}$ bin up to the height specified. Each row shows the (bin-averaged) observed values (+) and model estimates (circles). Data from Period $1(\mathbf{a}, \mathbf{c})$ and Period $2(\mathbf{b}, \mathbf{d})$ are shown. The number of observations contributing to each bin is illustrated in the third column (row) of the top (bottom) row graphs.

Model performance of mixing ratio is strong versus METAR measurements at both the 10:10 and 10:50 missed landings (Table 3).

Model-estimated horizontal wind speed shows overestimation in time versus Twin Otter measurements except over the urban core of Detroit (roughly 10:14-10:17 UTC) near $520 \mathrm{~m}$ a.g.l. Twin Otter observations capture the wind speed decrease (increase) on the approach (take-off) of the missed landings more clearly than do model estimates. During the Flight \#13 period, model-estimated and wind profilermeasured horizontal wind speed show strong coherence over the column (Fig. 6). Model performance of wind direction versus Twin Otter observations is erratic in time (Fig. 5), with smallest bias at the time of missed landings.

\subsection{Summary of model verification}

Comparison of model temperature estimates with Twin Otter flight measurements yields a distinct model cold bias of $2-3 \mathrm{~K}$ over approximately the lowest $500 \mathrm{~m}$ a.g.l. This bias may be influenced by a $1 \mathrm{~K}$ warm bias common to commercial aircraft temperature measurements. Conversely, model comparison to radiosonde measurements at KDTX reveals a warm bias of about $1 \mathrm{~K}$ in the corresponding vertical region and aloft with an RMSE of 2-4 K.

Twin Otter measurements of mixing ratio are consistently and significantly higher than both model estimates and METAR observations where overlap exists. The latter two sources show excellent correspondence during the Flight \#13 missed landings. Comparison of model estimates to radiosonde measurements also yields small RMSE with no clear bias in the lowest $500 \mathrm{~m}$ a.g.l. A potential dry bias in radiosonde measurement may explain evidence of a moist model bias aloft during Period 2. 
Model estimates of horizontal wind speed consistently overestimate both Twin Otter and radiosonde measurements with a mean bias of roughly $1-2 \mathrm{~ms}^{-1}$ and RMSE of 2$3 \mathrm{~ms}^{-1}$, though better performance is found versus the VHF wind profiler. Verification within the ABL is limited here, but suggests that model estimates of horizontal wind speed are likely too strong (by approximately $2 \mathrm{~ms}^{-1}$ ). Comparisons show no common model wind speed bias versus height or time, though model estimated $h_{\mathrm{ABL}}$ may be contributing to local wind, temperature or moisture biases. METAR and Twin Otter wind measurements correspond well during the missed landings. Model estimated wind direction adheres well to both radiosonde and profiler measurements with local error seldom exceeding 30 degrees. This result is particularly important for validating the penetration of lake-breeze fronts in this environment.

\section{Results}

\subsection{Sensitivity of the morphology to changing surface cover resolution}

This study hypothesizes sensitivity of mesoscale modeled urban meteorology to the scale of urban representation. This hypothesis presumes that the morphology of the urban environment changes with the scale of representation. Frequency distributions of urban land surface type reveal that nearly 20 percent more of the fourth grid of the model domain is classified as "medium intensity urban" in case 120 s than case $10 \mathrm{~s}$ (Fig. 7), resulting in change to the local and overall urban morphology accordingly (Table 1). Statistical assessment (coefficient of variation) of the principal morphology parameters $\left(z_{R}, f_{\mathrm{URB}}\right.$, and $\left.R / R_{\mathrm{W}}\right)$ demonstrates a consistent loss of variability with decreasing resolution of the urban surface. This loss of variability is statistically significant (via 2 sample $F$-test) between all cases for the $\mathrm{f}_{\text {URB }}$ parameter, but only compared with case $60 \mathrm{~s}$ and $120 \mathrm{~s}$ for $z_{R}$ and $R / R_{\mathrm{W}}$. These results establish a need to diagnose the response of the local meteorology.

\subsection{Quantifying the meteorological response}

Analysis of the change in model meteorology over the urban core of Detroit-Windsor concentrates on two areas: the surface energy balance and the meteorology within and above the urban canopy, including static and dynamic stability, temperature, moisture, turbulence kinetic energy, horizontal and vertical winds and estimated boundary layer depth. The evaluation examines (1) change to the grid-average value of pertinent quantities, (2) sources of local change within the grid and (3) variation in time of the root-mean-squareddeviation (RMSD) of pertinent quantities between case studies. The latter assessment provides a sound estimate of the magnitude of change that can be anticipated as a result of using coarser mesoscale urban representation, effectively
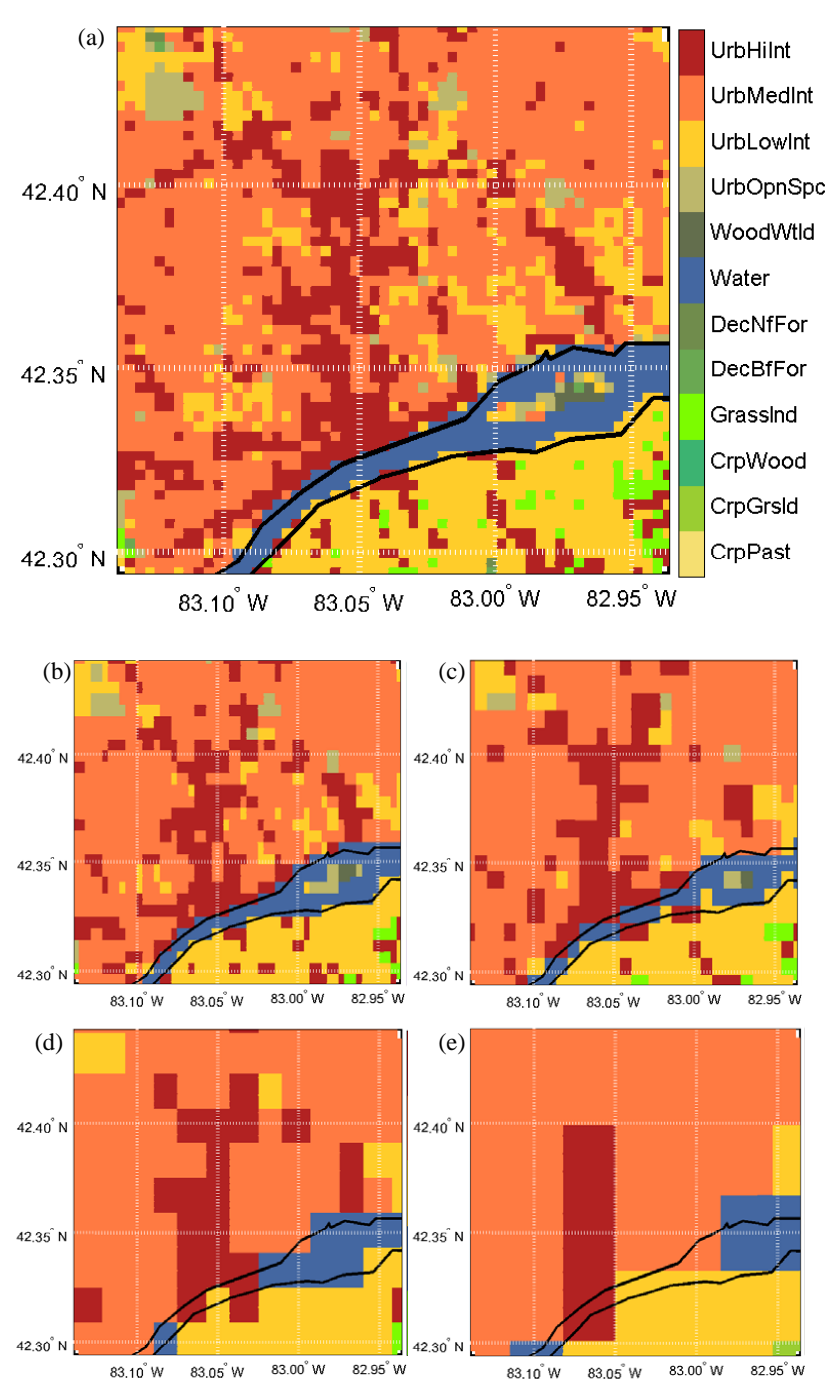

Fig. 7. Surface cover type over the fourth model grid of the DetroitWindsor domain using $10 \mathrm{~s}$ (a), 20s (b), 30s (c), 60s (d) and $120 \mathrm{~s}$ (e) surface cover resolution data. Color scheme in all subplots corresponds to that in (a). See Appendix A for translation of abbreviations in legend.

contributing a rough "error bar" to quantities of interest to mesoscale atmospheric modelers. The RMSD assessment includes comparisons of all case studies $(10 \mathrm{~s}, 20 \mathrm{~s}, 30 \mathrm{~s}, 60 \mathrm{~s}$, $120 \mathrm{~s})$. The remaining assessments focus exclusively on the change from case $10 \mathrm{~s}$ to case $20 \mathrm{~s}$ to understand the significance of the neighborhood scale on urban meteorology and the magnitude of change resulting from a very small reduction in the scale of urban representation.

In conjunction with these case studies, model resolved structures are also examined for both periods of study. WRF simulations with well-mixed layers, horizontal resolution comparable to this study and sufficient stability $\left(-z_{i} / L<\right.$ 25 ), where $z_{i}$ is the depth of the well-mixed layer and $L$ is the Obukhov length scale (Obukhov, 1946; Monin and 
(a)

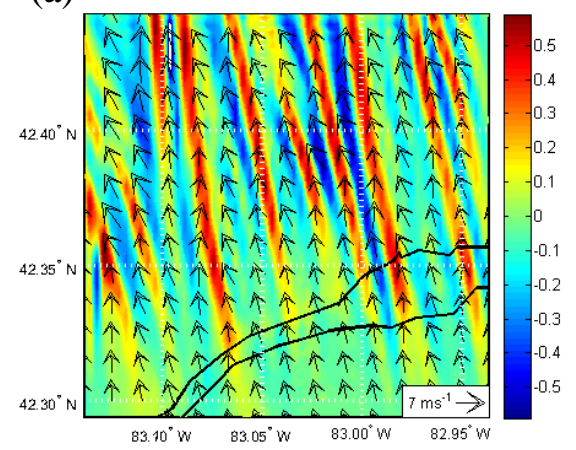

(b)

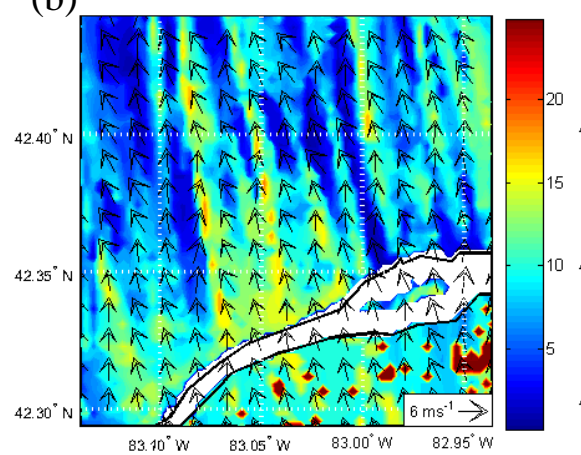

(c)

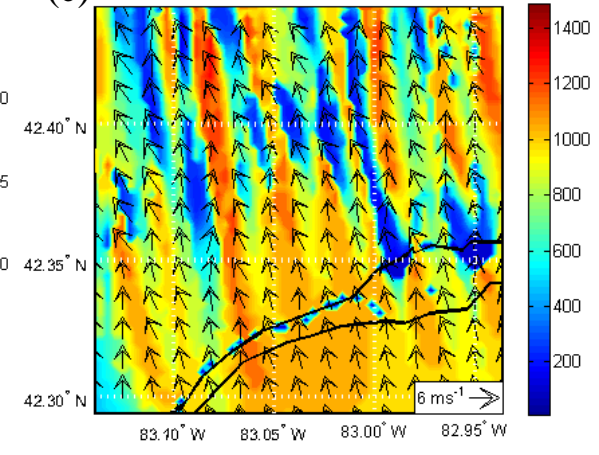

Fig. 8. Vertical velocity $\left(\mathrm{ms}^{-1}\right)$ at the midpoint of the second lowest layer above the surface ( $\sim 91 \mathrm{~m}$ a.g.l.) (a), a non-dimensional Obukhov stability parameter $(-z i / L)(\mathbf{b})$ and ABL depth $(\mathrm{m})(\mathbf{c})$, all evaluated over the 4th model grid in case $10 \mathrm{~s}$ at 18:20 UTC 24 June 2007. All figures show horizontal wind at the midpoint of the lowest model layer (except (a)) in black vectors, scaled by the reference vector at the lower right, each vector being separated by approximately four grid cells.

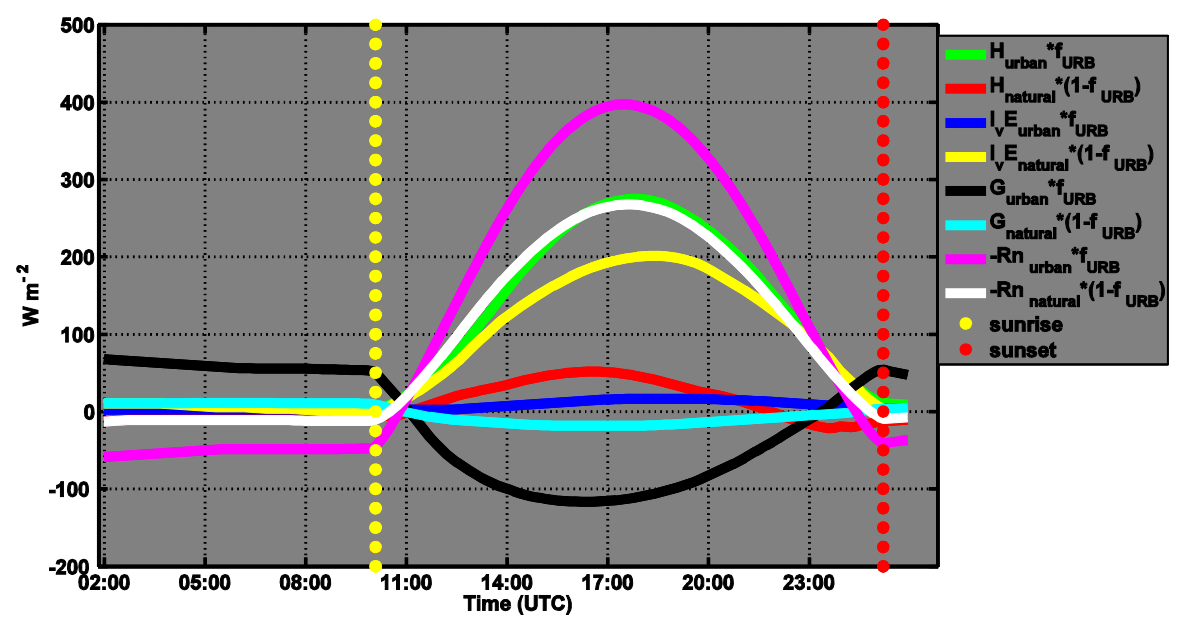

Fig. 9. Flux components of the average surface energy budget over the fourth model grid for case $10 \mathrm{~s}$. Fluxes are shown versus time (UTC) for the Period 02Z 24 June - 01Z 25 June 2007 in units of $\mathrm{Wm}^{-2}$ for the components: urban surface sensible heat (green), natural surface sensible heat (red), urban surface latent heat (blue), natural surface latent heat (yellow), urban surface ground heat (black), natural surface ground heat (cyan), (negative) urban surface net radiation (pink) and (negative) natural surface net radiation (white). Approximate time of sunrise (sunset) is indicated by the yellow (red) dotted line.

Obukhov, 1954), frequently generate horizontal convective rolls (HCR) (Trier et al., 2004; Miao and Chen, 2008; Gutiérrez et al., 2010; LeMone et al., 2010). Where these conditions are met, simulations here also demonstrate HCR presence (Fig. 8). The rolls shown in the example here are approximately $2.5 \mathrm{~km}$ in width, satisfying the observed $3: 1$ ratio of HCR width to well-mixed layer ABL depth (Stull, 1988) and also exceeding the minimum model effective resolution (see Sect. 2.2), though more thorough observations are needed for sufficient verification of this behavior.

The change in land cover resolution from case $10 \mathrm{~s}$ to case $20 \mathrm{~s}$ creates an abundance of model grid cells with changed urban land cover type (Fig. 7). With the presence of the Detroit River, this also includes the transition of cells from urban to non-urban (including water) classification and vice versa. For grid-average values, a principal consequence of this change in land cover resolution is a slight shift in the overall distribution of urban land cover type toward higher urban intensities, masking some of the heterogeneity of the true urban surface.

\subsection{Surface energy budget response}

The surface energy budget for case $10 \mathrm{~s}$ (Fig. 9) illustrates the contribution of both the urban and natural surfaces to the local energy balance. A shift in grid-average urban intensity from case $10 \mathrm{~s}$ to case $20 \mathrm{~s}$ ( $\Delta$ grid-average $f_{\mathrm{URB}}=+0.014$ ) perturbs this surface energy balance. One of the more 

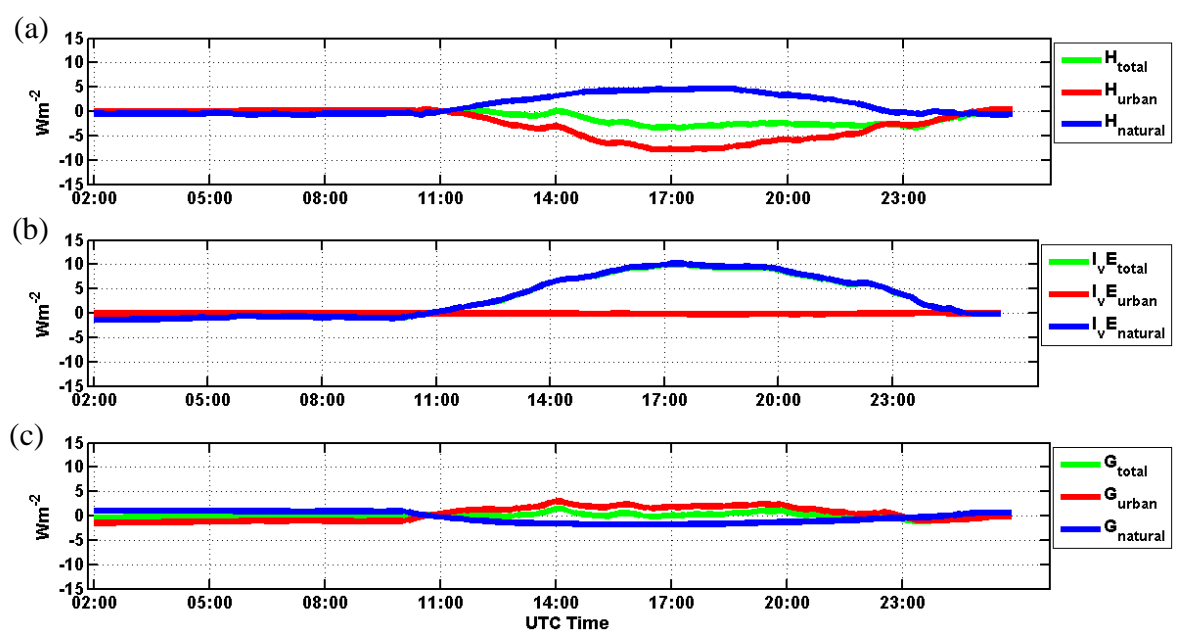

Fig. 10. Change of flux (case $10 \mathrm{~s}$ - case $20 \mathrm{~s}$ ) for sensible heat flux (a), latent heat flux (b) and ground heat flux (c) including the total (green) urban (red) and natural surface (blue) contributions to each. Change shown is averaged over all grid cells in the fourth model grid of the domain, plotted versus time (UTC) for the Period 02Z 24 June - 02Z 25 June 2007 in units of Wm ${ }^{-2}$.

conspicuous changes in the surface representation going from $10 \mathrm{~s}$ to $20 \mathrm{~s}$ resolution is the conversion of scattered, limited area natural surface class grid cells to urban grid cells south of the Detroit River over Windsor (Fig. 7). There are competing influences on urban canopy heat fluxes as a result of this change in grid-average $f_{\text {URB }}$. The immediate effect of a shift toward higher grid-average urban intensity is geometric: a taller canopy with increased building density, restricting canyon space. This reduces $u_{\mathrm{c}}$, enhancing the bulk transfer (drag) coefficient for heat $\left(C_{\mathrm{H}}\right)$ at the wall and road surfaces ( $C_{\mathrm{H}}$ also increases at the roof). The net result favors enhanced sensible and latent flux from the urban canopy $\left(l_{v} E_{\text {urban }}, H_{\text {urban }}\right)$. To restore equilibrium in the surface energy budget, however, the model iteratively reduces the skin surface temperature at the wall, road and roof surfaces, favoring a reduction of $G_{\text {urban }}, H_{\text {urban }}, l_{v} E_{\text {urban }}$ and the outgoing (longwave) radiation. These urban fluxes are additionally sensitive to local temperature and moisture gradients. The net effect on the individual heat flux components is assessed below.

Among all surface energy budget components, the latent heat flux $\left(l_{v} E_{\text {total }}\right)$ demonstrates the most significant response between case $10 \mathrm{~s}$ and case $20 \mathrm{~s}$ (Fig. 10). The contribution from the urban component $\left(l_{v} E_{\text {urban }} f_{\mathrm{URB}}\right)$ is minimal (due to limited moisture availability $(\beta)$ ), remaining below $10 \mathrm{Wm}^{-2}$ at peak. Thus, the change in $l_{v} E_{\text {total }}$ derives principally from the natural surface component of the grid cells $\left(\left(1-f_{\mathrm{URB}}\right) l_{v} E_{\text {natural }}\right)$ during the daytime when $l_{v} E_{\text {natural }}$ is strongest. The change in $f_{\mathrm{URB}}$ contributes toward the bulk of the daytime decrease $\operatorname{in} l_{v} E_{\text {total }}$ with $l_{v} E_{\text {natural }}$ responsible for the remainder. The latent heat flux from a vegetation-covered surface here derives mostly from canopy evapotranspiration, parameterized by the Penman-
Monteith relation (Monteith, 1981). The grid-average contributions to available energy changes little between cases; the change in $l_{v} E_{\text {natural }}$ derives largely from the water vapor demand at the lowest model layer ( $\sim 28 \mathrm{~m}$ a.g.l.), which varies locally. The RMSD of $l_{v} E_{\text {total }}$ (Fig. 11) over the urban core peaks at $45 \mathrm{Wm}^{-2}$ at 18:00 UTC (14:00 LT), coincident with the time of the strongest flux (Fig. 9) and nearly 25 percent of its value. RMSD increases monotonically, in phase, for case $10 \mathrm{~s}$ versus progressively coarser cases, approaching 35 percent of the total flux value for case $10 \mathrm{~s}$ vs. case $120 \mathrm{~s}$. This demonstrates significant daytime sensitivity of model estimated $l_{v} E_{\text {total }}$ to the scale of urban representation and the potential gain from use of the neighborhood scale (case $10 \mathrm{~s}$ ) in urban surface representation. It also suggests that much coarser representations yield only a marginal increase in RMSD from the neighborhood scale.

The response of the surface sensible heat flux $\left(H_{\text {total }}\right)$ to the land cover resolution change entails contributions from both the urban $\left(H_{\text {urban }}\right)$ and natural surface $\left(H_{\text {natural }}\right)$ components. Daytime grid-average $H_{\text {total }}$ increases from case $10 \mathrm{~s}$ to case $20 \mathrm{~s}$, the sum of an increase from $H_{\text {urban }} f_{\text {URB }}$ and a decrease from $H_{\text {natural }}\left(1-f_{\mathrm{URB}}\right)$ (Fig. 10). The net increase in $f_{\text {URB }}$ reduces the proportion of total flux from natural surfaces contributing partly toward the early afternoon reduction of $H_{\text {natural }}\left(1-f_{\mathrm{URB}}\right) . H_{\text {natural }}$ itself also decreases due to the reduced daytime natural surface skin temperature, shrinking the local natural skin surface-to- $2 \mathrm{~m}$ temperature gradient and, hence, the flux. While the grid-average contribution of $H_{\text {urban }} f_{\text {URB }}$ to $H_{\text {total }}$ is positive, grid-average change to $H_{\text {urban }}$ itself is negative. The skin surface temperature reduction along the canopy roof, walls and road grows to $0.5 \mathrm{~K}$ by mid-afternoon, with diagnostic canyon air temperature $\left(T_{\mathrm{c}}\right)$ decreasing by approximately half that. Additionally, the shift 

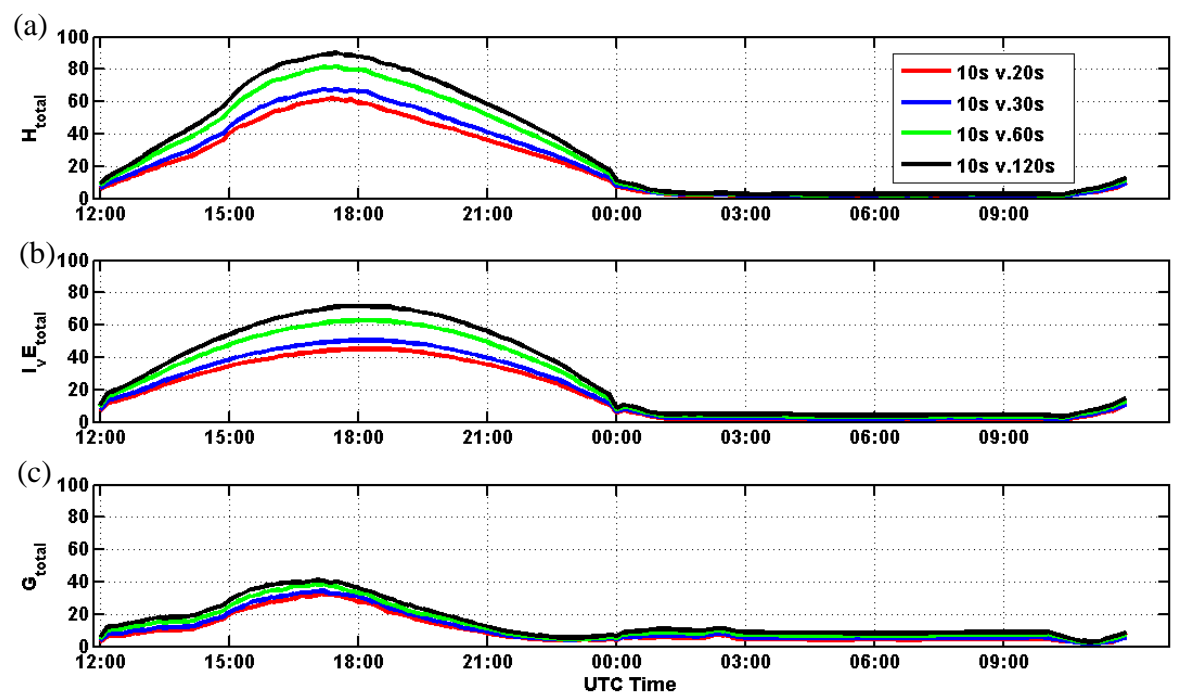

Fig. 11. RMSD of selected surface heat flux quantities over the fourth model grid for comparison of case $10 \mathrm{~s}$ and others of differing land cover resolution (in arc-seconds), averaged over all available data in Period 1 and Period 2. RMSD is shown versus time of day (UTC time) in units of $\mathrm{Wm}^{-2}$ for total surface sensible heat flux (a), total surface latent heat flux (b) and total ground heat flux (c).

toward higher urban intensity favors greater building density, at the expense of canyon width. In the afternoons, the peak temperature difference between the roof surface and the air above the canopy $(\sim+6 \mathrm{~K})$ is considerably smaller than that between the canyon wall or road surfaces and the canyon air temperature $(\sim+9 \mathrm{~K},+12 \mathrm{~K}$, respectively), not shown here. Combined, these changes reduce grid-average $H_{\text {urban }}$ by approximately $8 \mathrm{Wm}^{-2}$ by mid-afternoon from case $10 \mathrm{~s}$ to case $20 \mathrm{~s}$. Despite the grid-average reduction of $H_{\text {urban }}$ the grid-average increase of $f_{\mathrm{URB}}$ forces a net increase in grid-average $H_{\text {urban }} f_{\text {URB }}$. Accounting for those grid cells that change from urban to non-urban classification and vice versa (such as by consequence of resolution of the Detroit River), this further increases $H_{\text {urban }} f_{\text {URB }}$, resulting in a net increase of approximately $10 \mathrm{Wm}^{-2}$ in mid-afternoon, a four percent enhancement of its original contribution in case $10 \mathrm{~s}$ (Fig. 9).

The RMSD of $H_{\text {total }}$ (Fig. 11) over the urban core peaks at $62 \mathrm{Wm}^{-2}$ around 17:30 UTC (13:30 LT), coincident with the time of the strongest $H_{\text {urban }} f_{\mathrm{URB}}$ (Fig. 9) and 18 percent of $H_{\text {total }}$. As with $l_{v} E_{\text {total }}$, RMSD increases monotonically, in phase, for case $10 \mathrm{~s}$ versus progressively coarser cases, approaching 27 percent of the total flux value for case $10 \mathrm{~s}$ vs. case $120 \mathrm{~s}$, further demonstrating significant local sensitivity.

Grid-average change to ground heat flux $\left(G_{\text {total }}\right)$ from case $10 \mathrm{~s}$ to $20 \mathrm{~s}$ is virtually negligible (Fig. 10), but is the result of opposing change in the urban $\left(G_{\text {urban }} f_{\text {URB }}\right)$ and natural surface contributions $\left(G_{\text {natural }}\left(1-f_{\text {URB }}\right)\right)$ that can result in more substantial changes locally. The $G_{\text {natural }}\left(1-f_{\mathrm{URB}}\right)$ contribution registers a grid-average decrease in magnitude up to $2 \mathrm{Wm}^{-2}$ (both day and night). As with sensible heat flux, this decrease is a result of reduction to both $\left(1-f_{\mathrm{URB}}\right)$ and
$G_{\text {natural }}$. The decreased daytime natural surface skin temperature is nearly balanced by increased nocturnal temperature, reducing the local temperature gradient across the natural skin surface and, thus, $G_{\text {natural }}$. Increased grid-average $f_{\text {URB }}$ at case $20 \mathrm{~s}$ increases building density and thus favors weighting rooftop "ground" heat flux more heavily than road "ground" heat flux. This change favors decreased daytime ground heat flux $\left(\sim 2-3 \mathrm{Wm}^{-2}\right)$ and slightly increased nighttime flux. The contribution to total ground heat flux, $G_{\text {urban }} f_{\mathrm{URB}}$, shows a net increase in magnitude $\left(2-3 \mathrm{Wm}^{-2}\right.$ during the afternoon, $1 \mathrm{Wm}^{-2}$ at night), due to increased grid-average $f_{\text {URB }}$.

The RMSD of $\mathrm{G}_{\text {total }}$ (Fig. 11) over the urban core peaks at $32 \mathrm{Wm}^{-2}$ around 17:00 UTC (13:00 LT), coincident with the time of its strongest magnitude (Fig. 9) and 24 percent of $G_{\text {total }}$. RMSD increases for case $10 \mathrm{~s}$ versus progressively coarser cases, but with proportionally smaller increments than $H_{\text {total }}$ or $l_{v} E_{\text {total }}$, approaching 30 percent of the total flux value for case $10 \mathrm{~s}$ vs. case $120 \mathrm{~s}$.

\subsection{Meteorological response}

The daytime skin surface temperature of the urban solid surfaces (roof, wall, road) peaks around $10 \mathrm{~K}$ higher than the natural surface in this study, preceding peak air temperature above the canopy ( 22:00 UTC) by about $4 \mathrm{~h}$ (not shown). Consequently, the increased urbanization in case $20 \mathrm{~s}$ versus case $10 \mathrm{~s}$ ( $\Delta$ grid-average $\left.f_{\mathrm{URB}}=+0.014\right)$ increases the gridaverage skin surface temperature by up to $0.2 \mathrm{~K}$. This result confirms expectations of increased surface (skin) temperature associated with increased urban intensity. The natural skin surface temperature incurs little change except where 
grid cells are reassigned from land to water cover or viceversa as a result of resolution of the Detroit River.

Within the urban canyon, the model estimated air temperature $\left(T_{\mathrm{c}}\right)$ scalar wind speed $\left(u_{\mathrm{c}}\right)$ and water vapor mixing ratio $\left(q_{\mathrm{c}}\right)$ are subject to variation in canyon geometry and heat flux. Comparing case $10 \mathrm{~s}$ and case $20 \mathrm{~s}$, the increased ratio of $R / R_{\mathrm{W}}$ and slight daytime (nightime) decrease (increase) of surface skin temperature along the canyon walls and road in case $20 \mathrm{~s}$ decrease grid-average $T_{\mathrm{c}}$ up to $0.2 \mathrm{~K}$ in the afternoon and increase up to $0.1 \mathrm{~K}$ overnight. The $u_{\mathrm{c}}$ quantity demonstrates a slight grid-average reduction (less than $\left.0.1 \mathrm{~ms}^{-1}\right)$. This is anticipated due to reduced mean canyon space at higher urban intensity. The grid-average $q_{\mathrm{c}}$ shows little change. Local response in canyon meteorology is more substantial, vulnerable to change in the above-canopy wind speed and local canopy height. Versus case $20 \mathrm{~s}$, the peak of $T_{\mathrm{c}}, u_{\mathrm{c}}$ and $q_{\mathrm{c}}$ RMSD (Fig. 12) is approximately $0.3 \mathrm{~K}$, $0.2 \mathrm{~ms}^{-1}$ and $0.2 \mathrm{~g} \mathrm{~kg}^{-1}$, respectively. Normalized by the mean, $u_{\mathrm{c}}$ RMSD is greatest, though more precise diagnosis of street canyon flow requires more explicit resolution as in a computational fluid dynamics model. RMSD increases consistently for comparison of case $10 \mathrm{~s}$ versus progressively coarser resolution test cases, though evening change in $\mathrm{q}_{c}$ shows some variability.

Above the canopy, there is also evidence of a response in the meteorology. Examining the sign of $L$, the static stability of the urban environment in these case studies shows a consistently unstable daytime surface layer after sunrise. A largely stable nighttime surface layer develops abruptly after sunset. Being a function of surface heat flux, the transition of $L$ from daytime static instability to nighttime static stability is non-uniform and progresses inversely to the urban intensity. For Periods 1 and 2, (sunset $\sim 01: 12$ UTC) most developed, open space type urban land cover surfaces become statically stable within 30 minutes of 23:00 UTC, low intensity urban $\sim 23: 50$ UTC, medium intensity urban $\sim 00: 30$ UTC and high intensity urban $\sim 01: 30$ UTC. Low-level wind speed remains generally $\leq 3 \mathrm{~ms}^{-1}$ across the grid. Model estimates reveal limited, sporadic areas of static instability overnight over the high intensity urban surfaces, otherwise vacillating between weak and strong static stability. Around the time of sunrise ( $\sim 10$ :00 UTC), high intensity urban surface transition to static instability precedes the rest of the domain by about $30 \mathrm{~min}$. The remaining urban surface types change between 10:40 and 11:00 UTC. Thus, local change in urban surface classification at some coarser representation may drastically alter the overlying model estimated static stability. This result is keenly pertinent to model applications sensitive to surface layer vertical mixing in the evenings and overnight. Assessment of the local dynamic stability by way of the bulk Richardson number $\left(R i_{\mathrm{b}}\right.$ : Richardson, 1920) clearly distinguishes the dynamically unstable daytime well-mixed ABL from the laminar flow above and also reveals some difference in the evening residual turbulence strength between days during Period 1. Changes in the surface representation from case
$10 \mathrm{~s}$ to case $20 \mathrm{~s}$ provoke a patchwork of positive and negative change, mostly above $100 \mathrm{~m}$ a.g.l., but not enough to alter the flow classification.

Air temperature above the canopy responds to the change in $T_{\mathrm{S}}$ due to changing scale of surface representation. The phase shift in peak sensible heat flux between the urban canopy and natural surfaces (Fig. 9) suggests that change in $f_{\text {URB }}$ will affect the timing of the peak total sensible heat flux and, hence, the air temperature, contributing to the peak seen in Fig. 12a and d. Predictably, re-classification of urban grid cells to water grid cells from case $10 \mathrm{~s}$ to $20 \mathrm{~s}$ dominates the latter, given a typical $15-20 \mathrm{~K} T_{\mathrm{S}}$ difference in the afternoons. Wind direction subsequently influences the breadth of this effect, On the afternoon of 23 June, low-level easterly wind favors more substantial cold air advection resulting from increased water coverage in case $20 \mathrm{~s}$, not found on 24 June (south-southeast winds) or 7 July (west-southwest winds). Later that day, after 21:00 UTC, a Lake Erie lake breeze front (LBF) penetrates the domain from the south-southwest. The exchange of medium intensity urban land grid cells for water grid cells along the eastern part of the Detroit River in case $20 \mathrm{~s}$ versus case $10 \mathrm{~s}$ (Fig. 7) delays the advance of the LBF, as shown by the black-dashed highlighted region of Fig. 13. In contrast, the replacement of water grid cells with high intensity urban classification in case $60 \mathrm{~s}$ advances the LBF penetration by $1-2 \mathrm{~km}$ versus case $20 \mathrm{~s}$ (green-dashed highlighted region in Fig. 13), more closely emulating the local LBF representation in case $10 \mathrm{~s}$. Some local LBF acceleration and deceleration caused by changed urban intensity are also evident across the grid when comparing case $10 \mathrm{~s}, 20 \mathrm{~s}$ and $60 \mathrm{~s}$. The purple-dashed highlighted region of Fig. 13 shows how scattered areas of high intensity urban surfaces in case $10 \mathrm{~s}$ and $20 \mathrm{~s}$ (Fig. 7) accelerate the local LBF penetration versus case $60 \mathrm{~s}$ where only low intensity urban surfaces are found. Coastline resolution to the east of Windsor also affects the placement of a thermal internal boundary layer on 24 June. As the synoptic-scale wind rotates from south to southeast during the day, the fetch incorporates a progressively longer Period over the cooler Lake St. Clair surface prior to reaching eastern Detroit. Its expansion into the urban core region is accelerated in case $20 \mathrm{~s}$ versus case $10 \mathrm{~s}$, providing up to a $1.5 \mathrm{~K}$ difference locally in air temperature above the canopy ( $T_{\mathrm{a}} \sim 28 \mathrm{~m}$ a.g.l.) between cases.

The RMSD of $T_{\mathrm{a}}$ peaks at $0.2 \mathrm{~K}$ in the early afternoon (Fig. 12) for case $10 \mathrm{~s}$ vs. $20 \mathrm{~s}$, slightly less than RMSD of $T_{\mathrm{c}}$. Comparing case $10 \mathrm{~s}$ to coarser resolutions, RMSD of air temperature shows only modest increases. Air temperature above the urban canopy $\left(T_{\mathrm{a}}\right)$ and higher in the ABL appears relatively insensitive to systematic change in the urban morphology except in local circumstances as described above.

The effect of changed surface representation has a dichotomous effect on TKE. Increased urbanization at case $20 \mathrm{~s}$ leads to a net increase in mean canopy height, promoting mechanical production of turbulence and resulting in a net 


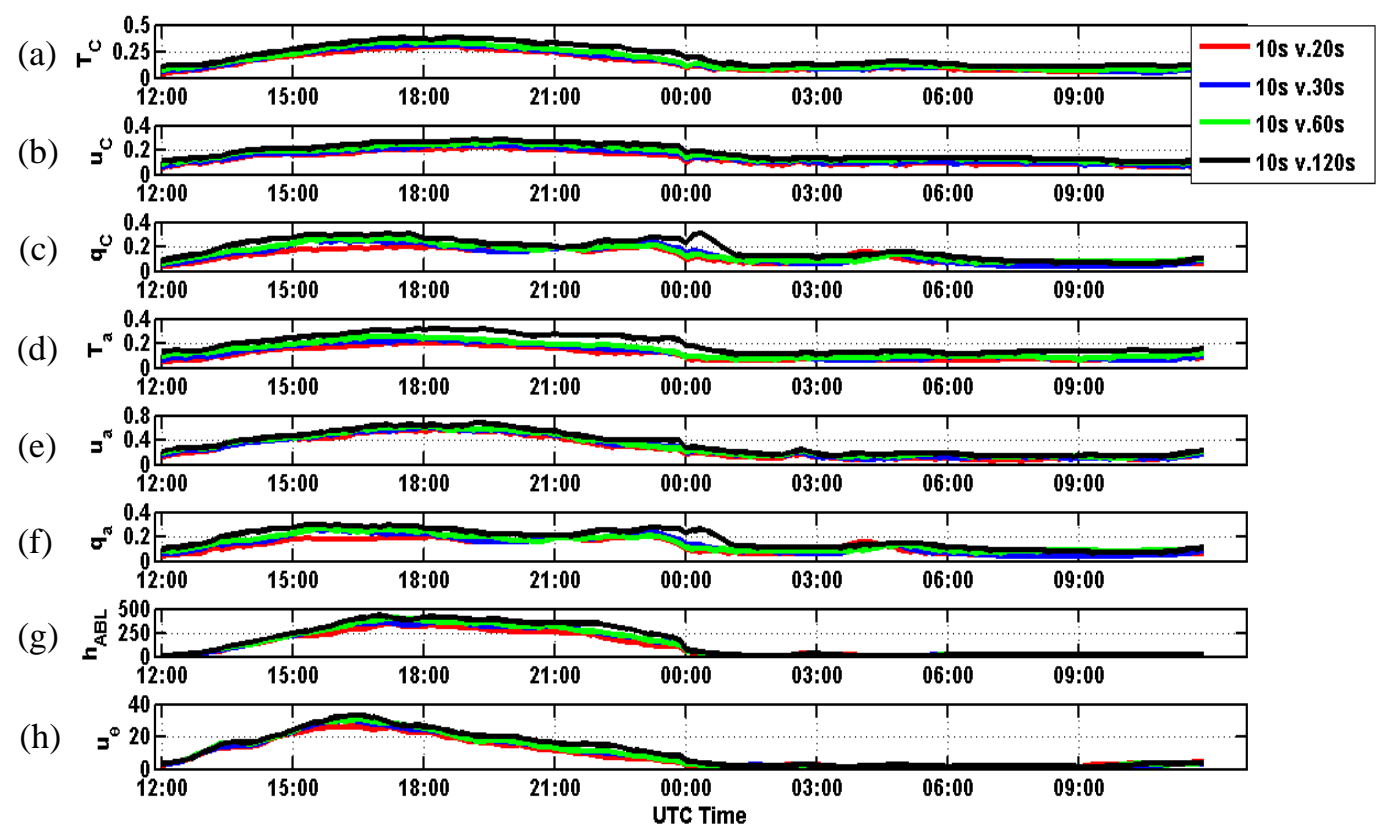

Fig. 12. RMSD of selected meteorological quantities over the fourth model grid for comparison of case $10 \mathrm{~s}$ and others of differing land cover resolution (in arc-seconds), averaged over all available data in Period 1 and Period 2. RMSD is shown versus time of day (UTC time) in units of $\mathrm{K}$ for (a) canyon temperature $\left(T_{\mathrm{c}}\right), \mathrm{ms}^{-1}$ for $(\mathbf{b})$ canyon wind speed $\left(u_{\mathrm{c}}\right)$ and $\mathrm{g} \mathrm{kg}^{-1}$ for (c) canyon water vapor mixing ratio $\left(q_{\mathrm{c}}\right)$, $\mathrm{K}$ for (d) lowest model layer ( $28 \mathrm{~m}$ a.g.1.) temperature (Ta), $\mathrm{ms}^{-1}$ for (e) lowest model layer wind speed $\left(u_{\mathrm{a}}\right), \mathrm{g} \mathrm{kg}^{-1}$ for $(\mathbf{f}) \mathrm{lowest}_{\mathrm{model}}$ layer water vapor mixing ratio $\left(q_{\mathrm{a}}\right), \mathrm{m}$ for $(\mathrm{g})$ boundary layer depth $(\mathrm{hABL})$ and degrees for $(\mathbf{h})$ lowest model layer wind direction $\left(u_{\theta}\right)$.

gain in grid-average TKE near the surface. When the wind direction and strength favors advection of the daytime gridaverage cooling influence of the increased water coverage in case $20 \mathrm{~s}$, the grid-average cooler surface slightly weakens the strength of thermal plume updrafts and downdrafts, concurrently reducing TKE aloft within the boundary layer and thus slightly reducing grid-average model estimated $h_{\mathrm{ABL}}$, parameterized according to TKE strength (Janjic, 2002).

Locally, as the buoyant production of TKE in the ABL varies according to change in surface thermal properties, and shifting wind direction varies TKE strength, so does the model-estimated $h_{\mathrm{ABL}}$ also vary. The RMSD of $h_{\mathrm{ABL}}$ reveals considerable variability during the daytime, peaking above $300 \mathrm{~m}$ in the early afternoon (Fig. 12). Comparing case $10 \mathrm{~s}$ versus progressively coarser urban surface representations yields RMSD exceeding $400 \mathrm{~m}$.

The variation of $q$ with surface representation follows the change in $h_{\mathrm{ABL}}$. Reduction of grid-average $h_{\mathrm{ABL}}$ at case $20 \mathrm{~s}$ reduces dry air entrainment from aloft and leads to a gridaverage net increase of $q$ (up to $0.1 \mathrm{~g} \mathrm{~kg}^{-1}$ ) in the well-mixed layer during the afternoon. RMSD of $q_{a}$ peaks at $0.2 \mathrm{~g} \mathrm{~kg}^{-1}$ in the afternoon versus case $20 \mathrm{~s}$, expanding up to $0.3 \mathrm{~g} \mathrm{~kg}^{-1}$ versus case $120 \mathrm{~s}$ (Fig. 12).

With considerable variation in wind direction among Periods 1 and 2, the low-level (above-canopy) horizontal wind speed RMSD peaks between $0.5-0.7 \mathrm{~ms}^{-1}$ during the afternoon for comparison of the neighborhood scale to coarser scales (Fig. 12). Corresponding wind direction RMSD peaks in the early afternoon during ABL growth, reaching 25 degrees for comparison versus case $20 \mathrm{~s}$ and up to 35 degrees for case $120 \mathrm{~s}$. This sensitivity is of particular interest to the Detroit-Windsor metropolitan area, where such deviation can affect the timing and extent of influence of on-shore flow or LBF penetration.

\section{Conclusions}

The sensitivity of model mesoscale meteorology to the scale of representation of the urban surface is explored over several summer periods in the Detroit-Windsor metropolitan area. The response includes both periodic change (as a function of daily heating) and stochastic change (as from change in the direction and magnitude of low-level flow in response to varying surface representation). The "effective model" resolution of approximately $2.1 \mathrm{~km}$ in the finest grid inhibits explicit inter-case comparison of the fine scale structure that would be expected to develop in response to a changing surface morphology; the model dampens this part of the KE spectrum and with it the variance of sensitivity to the surface representation. However, the surface energy budget and other near-surface meteorological quantities forced largely by the surface parameterizations can be expected to show demonstrable sensitivity to change in the surface representation. 
(a)

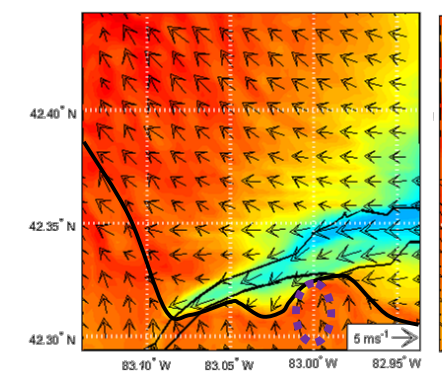

(d)

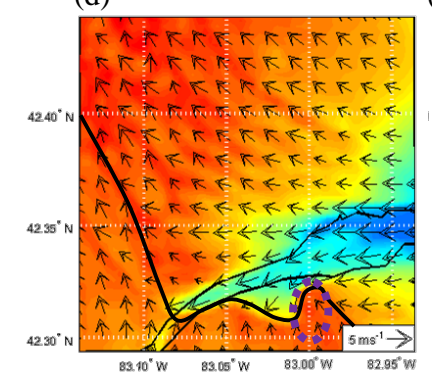

(g)

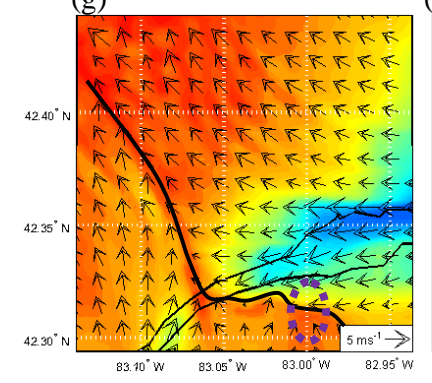

(b)

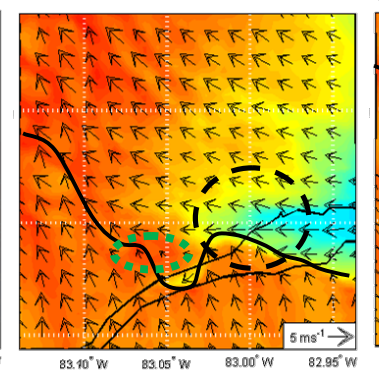

(e)

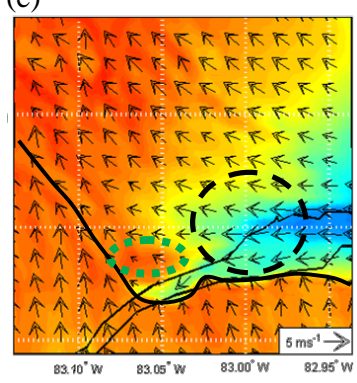

(h)

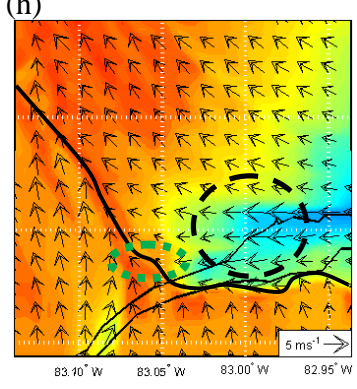

(c)

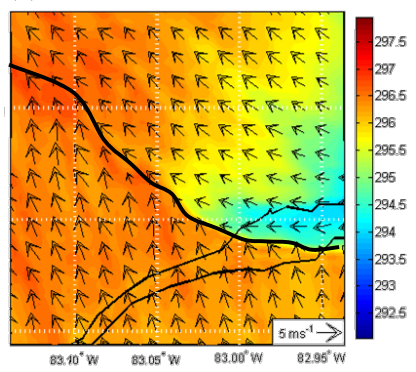

(f)

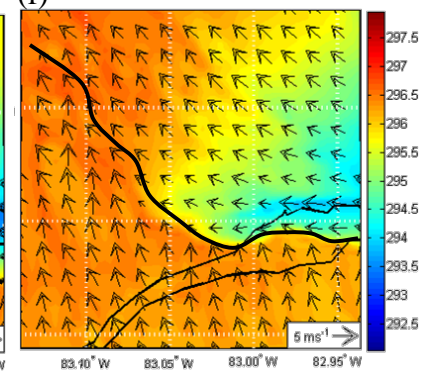

(i)

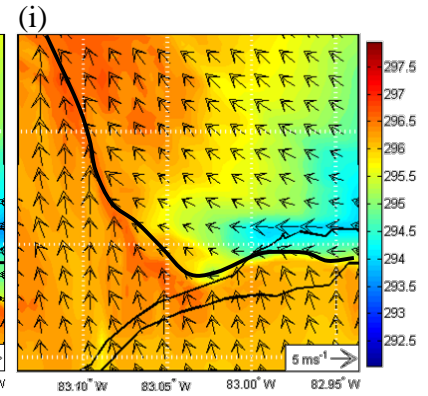

Fig. 13. Temperature (K), at the lowest model layer ( $28 \mathrm{~m}$ a.g.1.) over the fourth model grid of the domain at 22:10 (a, d, g), $22: 50$ (b, e,

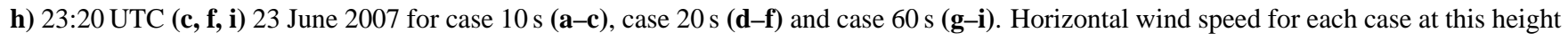
is shown in vectors scaled by the reference vector at the lower right. The estimated position of the lake breeze front is indicated by the thick black contour. The dashed ovals highlight particular examples of discrepancy in lake breeze front position between cases and are discussed further in the text.

In the surface energy budget, the natural surface component of the total latent heat flux $\left(l_{v} E_{\text {natural }}\left(1-f_{\mathrm{URB}}\right)\right)$ and the urban surface component of the total sensible heat flux $\left(H_{\text {urban }} f_{\mathrm{URB}}\right)$ are most sensitive, showing a net gridaverage daytime decrease and increase, respectively, of up to approximately $10 \mathrm{Wm}^{-2}$ for change from a 10 to 20 arcsecond resolution of the surface. Local change in urban classification as a consequence of scale change yields RMSDs of 20-30 percent of the total heat flux, demonstrating a considerable change in local surface energy balance within the urban core for a relatively small change in surface resolution. The fractional urban coverage $\left(f_{\mathrm{URB}}\right)$ parameter, which determines the extent of vegetation cover, contributes substantially to this sensitivity in the model, as anticipated from recent studies.
In the absence of explicit resolution of flow in the urban boundary layer, there is potential benefit to the neighborhood scale of resolution of the urban environment with respect to boundary layer depth estimation and in the timing of lake-breeze frontal passages or thermal internal boundary layers. High urban intensity, as found in the urban core of major cities, is found to delay the onset of nocturnal static stability at the surface up to $2-3 \mathrm{~h}$ versus nonurban surfaces. Increased urban intensity enhances mechanical production of turbulence kinetic energy just above the canopy, but has little influence of model estimated boundary layer depth. Afternoon estimated boundary layer depth RMSD versus the neighborhood scale exceeds $300 \mathrm{~m}$, demonstrating significant sensitivity. Scale of representation is also critical to cities with riparian or coastal interests, where temperature, turbulence kinetic energy and boundary layer depth are highly sensitive. For numerical weather 
prediction applications, this surface resolution increase from $20 \mathrm{~s}(\sim 617 \mathrm{~m})$ to $10 \mathrm{~s}(\sim 308 \mathrm{~m})$ under fair weather conditions provokes areas of conspicuous change scattered across the domain, with particular relevance to important mesoscale features such as the lake breeze circulation.

Modelers should be cognizant of the inherent error in state variable estimates evolving from a mesoscale urban surface parameterization. This study offers one attempt to quantify the nature and magnitude of sensitivity to scale and the potential error that arises with progressively coarser representations. Although the most acute response predictably corresponds to surface and low-level quantities, change in boundary layer depth and the timing of mesoscale circulations like lake-breeze fronts can yield broader impacts on real atmosphere simulations.

\section{Appendix A}

\section{Symbols, acronyms and abbreviations}

\begin{tabular}{|c|c|}
\hline $\mathrm{ABL}$ & Atmospheric Boundary Layer \\
\hline ACARS & $\begin{array}{l}\text { Aircraft Communications Addressing and Reporting } \\
\text { System }\end{array}$ \\
\hline a.g.l. & Above Ground Level \\
\hline AMDAR & Aircraft Meteorological Data Acquisition and Relay \\
\hline AWIP & NCEP Eta/NAM 212 grid model analysis \\
\hline BAQS-Met & Border Air Quality and Meteorology field campaign \\
\hline$C_{\mathrm{H}}$ & bulk transfer coefficient for heat \\
\hline CrpGrslnd & mixed cropland and grassland land surface type \\
\hline CrpPast & $\begin{array}{l}\text { mixed cropland and pasture land } \\
\text { surface type }\end{array}$ \\
\hline CrpWood & mixed cropland and woodland land surface type \\
\hline CFD & Computational Fluid Dynamics \\
\hline $\mathrm{CRC}$ & (NOAA) Coastal Resources Center \\
\hline DecBfFor & deciduous broadleaf forest land surface type \\
\hline DecNfFor & deciduous needleleaf Forest land surface type \\
\hline DNS & Direct Numerical Simulation \\
\hline DTW & Detroit-Windsor \\
\hline E & kinematic moisture flux $\left(l_{\mathrm{v}} E=\right.$ latent heat flux $)$ \\
\hline$f_{\mathrm{URB}}$ & fractional urban coverage \\
\hline $\mathrm{g}$ & gram \\
\hline$G$ & ground heat flux \\
\hline$G_{\text {natural }}$ & $\begin{array}{l}\text { ground heat from the natural component of an } \\
\text { urbanized grid cell }\end{array}$ \\
\hline$G_{\text {total }}$ & $\begin{array}{l}\text { ground heat flux from the } G_{\text {urban }} \text { and } G_{\text {natural }} \\
\text { components of a grid cell }\end{array}$ \\
\hline$G_{\text {urban }}$ & ground heat flux from the urban canopy \\
\hline Grasslnd & grassland land surface type \\
\hline GPS & Global Positioning System \\
\hline$h$ & normalized building height \\
\hline $\begin{array}{l}h_{\mathrm{ABL}} \\
\mathrm{hPa}\end{array}$ & $\begin{array}{l}\text { atmospheric boundary layer depth } \\
\text { hecto-Pascal }\end{array}$ \\
\hline$H$ & sensible heat flux \\
\hline$H_{\text {natural }}$ & $\begin{array}{l}\text { sensible heat from the natural component of an } \\
\text { urbanized grid cell }\end{array}$ \\
\hline$H_{\text {total }}$ & $\begin{array}{l}\text { sensible heat flux from the } H_{\text {urban }} \text { and } H_{\text {natural }} \text { components } \\
\text { of a grid cell }\end{array}$ \\
\hline$H_{\text {urban }}$ & sensible heat flux from the urban canopy \\
\hline $\mathrm{Hz}$ & Hertz \\
\hline IrgCrpPst & irrigated cropland and pasture land surface type \\
\hline JJA & June-July-August \\
\hline $\mathrm{kg}$ & kilogram \\
\hline
\end{tabular}

\begin{tabular}{|c|c|}
\hline $\mathrm{km}$ & kilometer \\
\hline $\mathrm{K}$ & Kelvin \\
\hline$l_{\mathrm{v}}$ & latent heat of vaporization \\
\hline$l_{\mathrm{v}} E$ & latent heat flux \\
\hline$l_{\mathrm{v}} E_{\text {natural }}$ & $\begin{array}{l}\text { latent heat from the natural component of an urbanized } \\
\text { grid cell }\end{array}$ \\
\hline$l_{\mathrm{v}} E_{\text {total }}$ & $\begin{array}{l}\text { latent heat flux from the } l_{\mathrm{v}} E_{\text {urban }} \text { and } l_{\mathrm{v}} E_{\text {natural }} \text { components } \\
\text { of a grid cell }\end{array}$ \\
\hline$l_{\mathrm{v}} E_{\text {urban }}$ & latent heat flux from the urban canopy \\
\hline$L$ & Obukhov length scale \\
\hline LBF & Lake Breeze Front \\
\hline LES & Large Eddy Simulation \\
\hline $\begin{array}{l}\mathrm{LSM} \\
\mathrm{m}\end{array}$ & $\begin{array}{l}\text { Land Surface Model } \\
\text { meter }\end{array}$ \\
\hline $\mathrm{MHz}$ & MegaHertz \\
\hline $\mathrm{MxIrgCpP}$ & $\begin{array}{l}\text { mixed dry and irrigated cropland and pasture land } \\
\text { surface type }\end{array}$ \\
\hline METAR & aviation routine weather report \\
\hline MYJ & Mellor-Yamada-Janjic \\
\hline MNR & Ministry of Natural Resources \\
\hline NOAA & National Oceanic and Atmospheric Administration \\
\hline NCEP & National Centers for Environmental Prediction \\
\hline NLCD & National Land Cover Dataset \\
\hline NRC & National Research Council \\
\hline NWP & Numerical Weather Prediction \\
\hline NWS & National Weather Service \\
\hline ON & Ontario \\
\hline$p$ & pressure \\
\hline $\mathrm{Pa}$ & Pascal \\
\hline$q$ & $\begin{array}{l}\text { water vapor mixing ratio/component of turbulence } \\
\text { kinetic energy }\end{array}$ \\
\hline$q_{\mathrm{a}}$ & $\begin{array}{l}\text { water vapor mixing ratio at the mid-point of the lowest } \\
\text { model layer }\end{array}$ \\
\hline$q_{\mathrm{c}}$ & urban canyon water vapor mixing ratio \\
\hline$R$ & normalized building width \\
\hline$R i_{\mathrm{b}}$ & bulk Richardson number \\
\hline RANS & Reynolds Averaged Navier Stokes equations \\
\hline RMSD & Root-Mean-Squared Deviation \\
\hline RMSE & Room Mean Squared Error \\
\hline$R_{\mathrm{W}}$ & normalized street width \\
\hline $\mathrm{s}$ & second \\
\hline$T$ & temperature \\
\hline$T_{\mathrm{a}}$ & $\begin{array}{l}\text { air temperature at the mid-point of the lowest } \\
\text { model layer }\end{array}$ \\
\hline$T_{\mathrm{c}}$ & urban canyon air temperature \\
\hline$T_{\mathrm{S}}$ & skin surface temperature \\
\hline TKE & Turbulence Kinetic Energy \\
\hline$u_{\mathrm{a}}$ & $\begin{array}{l}\text { horizontal wind speed at the mid-point of the lowest } \\
\text { model layer }\end{array}$ \\
\hline$u_{\mathrm{c}}$ & urban canopy wind speed \\
\hline$u$ & (scalar) wind speed \\
\hline$u_{\theta}$ & wind direction \\
\hline UCM & Urban Canopy Model \\
\hline UrbHint & developed, high intensity urban land surface type \\
\hline UrbLint & developed, low intensity urban land surface type \\
\hline UrbMint & developed, medium intensity urban land surface type \\
\hline UrbOpsp & developed, open space urban land surface type \\
\hline USGS & United States Geological Survey \\
\hline UTC & Universal Coordinated Time \\
\hline VHF & Very High Frequency \\
\hline W & Watt \\
\hline WRF & Weather Research and Forecasting model \\
\hline WRF-ARW & Advanced Research WRF \\
\hline$x$ & model-estimated variable \\
\hline$\widehat{x}$ & $\begin{array}{l}\text { model-estimated variable interpolated to } \\
\text { observation space }\end{array}$ \\
\hline$y$ & observed variable \\
\hline$z_{R}$ & mean canopy height \\
\hline$\beta$ & moisture availability \\
\hline$\Delta x$ & grid cell width \\
\hline$\circ$ & degree \\
\hline
\end{tabular}


Acknowledgements. This work was supported by the Ontario Ministry of the Environment, Transboundary Air Research Grant. This work was made possible by the facilities of the Shared Hierarchical Academic Research Computing Network (SHARCNET: www.sharcnet.ca) and Compute/Calcul Canada.

The authors thank Sunny Wong and Jinliang Liu (Ontario Ministry of the Environment) for access to Ministry of Natural Resources land surface data, Katherine Hayden (Environment Canada) for air pressure measurements from Twin Otter flights and Shama Sharma (York University) for Harrow VHF wind profiler data.

Edited by: J. W. Bottenheim

\section{References}

Allwine, K. J., Leach, M. J., Stockham, L. W., Shinn, J. S., Hosker, R. P., Bowers, J. F., and Pace, J. C.: Overview of Joint Urban 2003 - an Atmospheric Dispersion Study in Oklahoma City, Symposium on Planning, Nowcasting and Forecasting in the Urban Zone, Seattle, Washington, USA, 11-14 January 2004, (S. CD-ROM, J7.1), 2004.

Arnfield, A.: Two decades of urban climate research: A review of turbulence, exchanges, of energy and water, and the urban heat island, Int. J. Climatol., 23, 1-26, 2003.

Ballish, B. and Kumar, V.: Systematic Differences in Aircraft and Radiosonde Temperatures, B. Am. Meteorol. Soc., 89, 16891707, 2008.

Balogun, A. A., Adegoke, J.O., Vezhapparambu, S., Mauder, M., McFadden, J. P. and Gallo, K.: Surface Energy Balance Measurements Above an Exurban Residential Neighbourhood of Kansas City, Missouri, Bound.-Lay. Meteorol., 133, 299-321, 2009.

Barlow, J. and Coceal, O.: A review of urban roughness sublayer turbulence, Met Office Meteorology Research and Development, Exeter, UK, 2009.

Best, M. J., Grimmond, C. S. B., and Villani, M. G.: Evaluation of the urban tile in MOSES using surface energy balance observations, Bound.-Lay. Meteorol., 118, 503-525, 2006.

Bornstein, R.: The 2-D URBMET urban boundary layer model, J. Appl. Meteorol., 14, 1459-1477, 1975.

Bougeault, P. and Lacarrère, P.: Parameterization of OrographyInduced Turbulence in a Mesobeta-Scale Model, Mon. Weather Rev., 117, 1872-1890, 1989.

Chen, F. and Dudhia, J.: Coupling an advanced landsurface/hydrology model with the Penn State/NCAR MM5 modeling system, Part I: Model description and implementation, Mon. Weather. Rev., 129, 569-585, 2001.

Cheng, H. and Castro, I.: Near wall flow over urban-like roughness, Bound.-Lay. Meteorol., 104, 229-259, 2002.

Chou, M.-D. and Suarez, M. J.: An efficient thermal infrared radiation parameterization for use in general circulation models, NASA Tech. Memo. 104606, 85 pp., 1994.

Christen, A. and Vogt, R.: Energy and Radiation Balance of a Central European City, Int. J., Climatol., 24, 1395-1421, 2004.

Coutts, A. M., Beringer, J., and Tapper, N. J.: Impact of Increasing Urban Density on Local Climate: Spatial and Temporal Variations in the Surface Energy Balance in Melbourne, Australia, J. Appl. Meteorol. Clim., 46, 477-493, 2007.
Delage, Y. and Taylor, P.: Numerical studies of heat island circulations, Bound.-Lay. Meteorol., 1, 201-226, 1970.

Garratt, J.: The atmospheric boundary layer, Cambridge University Press, Melbourne, Australia, 1992

Grimmond, C. S. B. and Oke, T.: Variability of evapotranspiration rates in urban areas, Proc. 15th International Congress of Biometeorology and International Conference on Urban climatology, Sydney, Australia, 8-12 November, 475-480, 1999a.

Grimmond, C. S. B. and Oke, T.: Aerodynamic Properties of Urban Areas Derived from Analysis of Surface Form, J. Appl. Meteorol., 38, 1262-1292, 1999 b.

Grimmond, C. S. B. and Oke, T.: Turbulent Heat Fluxes in Urban Areas: Observations and a Local-Scale Urban Meteorological Parameterization Scheme (LUMPS), J. Appl. Meteorol., 41, 792-810, 2002.

Grimmond, C. S. B., Blackett, M., Best, M., Baik, J. J., Belcher, S., Bohnenstengel, S., Calmet, I., Chen, F., Dandou, A., Fortuniak, K., Gouvea, M., Hamdi, R., Hendry, M. Kondo, H., Krayenhoff, S., Lee, S.-H., Loridan, T., Martilli, A., Masson, V., Miao, S., Oleson, K., Pigeon, G., Porson, A., Salamanca, F., Steeneveld, G.-J., Tombrou, M., Voogt, J., and Zhang, N.: The International Urban Energy Balance Models Comparison Project: First Results from Phase 1, J. Appl. Meteorol. Clim., 49, 1268-1292, 2010.

Gutiérrez, E. J., Gonzalez, J. E., Bornstein, R. D., Arend, M., Moshary, F., and Martilli, A.: Numerical Simulations of Sea Breeze Circulations and Urban Heat Islands in NYC with a High Resolution Urban-Mesoscaled Model (uWRF), Ninth Symposium on the Urban Environment, Keystone, Colorado, USA, 2-6 August, 9.2, 2010.

Hagishima, A., Narita, K.-I., and Tanimoto, J.: Field experiment on transpiration from isolated urban plants, Hydrol. Process, 21, 1217-1222, 2007.

Hocking, A. and Hocking, W.: Turbulence anisotropy determined by wind profiler radar and its correlation with rain events in Montreal, Canada, J. Atmos. Ocean. Tech., 24, 40-51, 2007.

Hong, S.-Y., Dudhia, J. and Chen, S.-H.: A Revised Approach to Ice Microphysical Processes for the Bulk Parameterization of Clouds and Precipitation, Mon. Weather Rev., 132, 103-120, 2004.

Janjic, Z.: Nonsingular Implementation of the Mellor-Yamada Level 2.5 Scheme in the NCEP Meso model, NCEP Office Note No. 437, National Centers for Environmental Prediction, Camp Springs, Maryland, USA, 61 pp., 2002.

Kain, J.: The Kain-Fritsch convective parameterization: An update, J. Appl. Meteorol., 43, 170-181, 2004.

Kain, J. and Fritsch, M.: Convective parameterization for mesoscale models: The Kain-Fritsch scheme, in: The representation of cumulus convection in numerical models, edited by: Emanuel, K. A. and Raymond, D. A., Meteor. Monogr., no. 24, American Meteorological Society, Boston, Massachusetts, USA, 165-170, 1993.

Kanda, M.: Progress in Urban Meteorology: A Review, J. Meteorol. Soc. Jpn., 85b, 363-383, 2007.

Kawai, T. and Kanda, M.: Urban Energy Balance Obtained from the Comprehensive Outdoor Scale Model Experiment, Part 1: Basic Features of the Surface Energy Balance, J. Appl. Meteorol. Clim., 49, 1341-1359, 2010.

Kim, J. and Baik, J.: A numerical study of thermal effects on flow and pollutant dispersion in urban street canyons, J. Appl. 
Meteorol., 38, 1249-1261, 1999.

Kusaka, H. and Kimura, F.: Coupling a Single-Layer Urban Canopy Model with a Simple Atmospheric Model: Impact on Urban Heat Island Simulation for an Idealized Case, J. Meteorol. Soc. Jpn., 82, 67-80, 2004.

Kusaka, H., Kondo, H., Kikegawa, Y., and Kimura, F.: A Simple Single-Layer Urban Canopy Model for Atmospheric Models: Comparison with Multi-Layer and Slab Models, Bound. Lay. Meteorol., 101, 329-358, 2001.

Lee, S.-H. and Park, S.-U.: A Vegetated Urban Canopy Model for Meteorological and Environmental Modeling, Bound.-Lay. Meteorol., 126, 73-102, 2008.

Leonardi, S., Orlandi, P. S., Djenidi, L., and Antonia, R.: Direct numerical simulations of turbulent channel flow with transverse square bars on one wall, J. Fluid Mech., 491, 229-238, 2003.

Macdonald, R.: Modelling the mean velocity profile in the urban canopy layer, Bound.-Lay. Meteorol., 97, 25-45, 2000.

Mamrosh, R., Baker, R., and Jirikowic, T.: A Comparison of ACARS WVSS and NWS Radiosonde Temperature and Moisture Data, Sixth Symposium on Integrated Observing Systems, Orlando, Florida, USA, 12-17 January 2002, 6.14, 2002.

Martilli, A.: Numerical study of urban impact on boundary layer structure: Sensitivity to Wind Speed, Urban Morphology and Rural Soil Moisture, J. Appl. Meteorol., 41, 1247-1266, 2002.

Martilli, A., Clappier, A., and Rotach, M.: An urban surface exchange parameterisation for mesoscale models, Bound.-Lay. Meteorol., 104, 261-304, 2002.

Masson, V.: A physically-based scheme for the urban energy budget in atmospheric models, Bound.-Lay. Meteorol., 94, 357-397, 2000.

Miao, S., Jiang, W., Wang, X., and Guo, W.: Impact assessment of urban meteorology and the atmospheric environment using urban sub-domain planning, Bound.-Lay. Meteorol., 118, 133-150, 2006.

Miao, S., Chen, F., LeMone, M. A., Tewari, M., Li, Q., and Wang, Y.: An Observational and Modeling Study of Characteristics of Urban Heat Island and Boundary Layer Structures in Beijing, J. Appl. Meteorol. Clim., 48, 484-501, 2009.

Miller, E., Wang, J., and Cole, H.: Correction for Dry Bias in Vaisala Radiosonde RH Data, in: Ninth ARM Science Team Meeting Proceedings, San Antonio, Texas, USA, 22-26 March, 1999.

Mills, G.: The Urban Canopy Layer Heat Island; IAUC Teaching Resources: http://www.urban-climate.org/, last access: 25 March 2010, 2004

Mlawer, E., Taubman, S., Brown, P., Iacono, M., and Clough, S.: Radiative transfer for inhomogeneous atmosphere: RRMT, a validated corelated-k model for the longwave, J. Geophys. Res., 102(D14), 16663-16682, 1997.

Monin, A. and Obukhov, A.: Basic laws of turbulent mixing in the atmosphere near the ground, Tr. Akad. Nauk SSSR Geofiz. Inst., 24, 163-187, 1954.

Myrup, L.: A numerical model of the urban heat island, J. Appl. Meteorol., 8, 908-918, 1969.

NOAA National Weather Service - Detroit/Pontiac, MI: Monthly Normals, Detroit, http://www.crh.noaa.gov/dtx/cms.php?n= monthlynormals, last access: 1 April 2010, 2010.

NOAA National Weather Service: Radiosonde Observations, http: //www.ua.nws.noaa.gov/factsheet.htm, last access: 25 March
2010, 2010.

Nunez, M. and Oke, T.: The energy balance of an urban canyon, J. Appl. Meteorol., 16, 11-19, 1977.

Obukhov, A.: Turbulence in an atmosphere with a non-uniform temperature, Trudy Inst. Theor. Geofiz. AN SSSR, 1, 95-115, 1946.

Offerle, B., Grimmond, C. S. B., Fortuniak, K., Kysik, K., and Oke, T. R.: Temporal variations in heat fluxes over a central European city centre, Theor. Appl. Climatol., 84, 103-115, 2006a.

Offerle, B., Grimmond, C. S. B., Fortuniak, K., and Pawlak, W.: Intraurban Differences of Surface Energy Fluxes in a Central European City, J. Appl. Meteorol. Clim., 45, 125-136, 2006 b.

Oke, T.: Canyon geometry and the nocturnal urban heat island: Comparison of scale model and field observations, Int. J. Climatol., 1, 237-254, 1981.

Oke, T.: The energetic basis of the urban heat island, Q. J. Roy. Meteor. Soc., 108, 1-24, 1982.

Oke, T.: Boundary Layer Climates, Routledge, New York, USA, 1987.

Pearlmutter, D., Krüger, E. L., and Berliner, P.: The role of evaporation in the energy balance of an open-air scaled urban surface, Int. J. Climatol., 29, 911-920, 2009.

Richardson, L.: The supply of energy from and to atmospheric eddies. Proceedings of the Royal Society of London A , 97, 354373, 1920.

Rotach, M.: On the influence of the urban roughness sublayer on turbulence and dispersion, Atmos. Environ., 33, 4001-4008, 1999.

Roth, M.: Review of atmospheric turbulence over cities, Q. J. Roy. Meteor. Soc., 126, 941-990, 2000.

Sailor, D. J.: Anthropogenic Heat and Moisture Emissions in the Urban Environment, Seventh International Conference on Urban Climate, Yokohama, Japan, 29 June-3 July, S-3, 2009.

Salamanca, F. and Martilli A.: A new Building Energy Model coupled with an Urban Canopy Parameterization for urban climate simulations - part II. Validation with one dimension offline simulations, Theor. Appl. Climatol., 99, 345-356, 2009.

Salamanca, F., Martilli, A., and Yagüe, C.: A numerical study of the urban boundary layer over Madrid during the DESIREX (2008) campaign with WRF, Ninth Symposium on the Urban Environment and 19th Symposium on Boundary Layers and Turbulence, Keystone, Colorado, USA, 2-6 August, 2010, 2010.

Schlünzen, K. H. and Katzfey, J. J.: Relevance of sub-grid-scale land-use effects for mesoscale models, Tellus, 55A, 232-246, 2003.

Skamarock, W. C.: Evaluating Mesoscale NWP Models Using Kinetic Energy Spectra, Mon. Weather Rev., 132, 3019-3032, 2004.

Skamarock, W. C., Klemp, J. B., Dudhia, J., Gill, D. O., Barker, D. M., Wang, W., and Powers, J. G.: A Description of the Advanced Research WRF Version 2, NCAR Tech. Note 468+STR, National Center for Atmospheric Research, Boulder, Colorado, USA, 88 pp., 2007.

Smagorinsky, J.: General circulation experiments with the primitive equations, Part I: The basic experiment, Mon. Weather Rev., 91, 99-164, 1963.

Srinivasan, R. and Bastian, M.: Twin Otter Operations in Southern Ontario in Support of Project BAQS-MET -Border Air Quality Study Meteorological - 2007, LTR-FR-285, National Research Council Canada, Ottawa, Ontario, Canada, 26 pp., 2008. 
Statistics Canada: Demographics - City of Windsor, http://www. citywindsor.ca/002358.asp, last access: 8 April 2010, 2006.

Turner, D., Lesht, B., Clough, S., Liljegren, J., Revercomb, H., and Tobin, D.: Dry Bias and Variability in Vaisala RS80-H Radiosondes: The ARM Experience, J. Atmos. Ocean. Tech., 20, 117132, 2003.

United States Census Bureau: Annual Estimates of the Population of Metropolitan and Micropolitan Statistical Areas: 1 April 2000 to 1 July 2009, http://www.census.gov/popest/metro/files/2009/ CBSA-EST2009-alldata.csv, last access: 8 April 2010, 2010.

Vukovich, F.: A study of the atmospheric response due to a diurnal heating function characteristic of an urban complex, Mon. Weather Rev., 101, 467-474, 1973.
Walker, C. E.: Methodology for the Evaluation of Natural Ventilation in Using a Reduced-Scale Air Model, Doctoral Thesis, Department of Architecture, Massachusetts Institute of Technology, USA, 211 pp., 2006.

Walton, A. and Cheng, A.: Large-eddy simulation of pollution dispersion in an urban street canyon -Part II: idealised canyon simulation, Atmos. Environ., 36, 3615-3627, 2002.

Walton, A., Cheng, A., and Yeung, W.: Large-eddy simulation of pollution dispersion in an urban street canyon - Part I: Comparison with field data, Atmos. Environ., 36, 3601-3613, 2002. 